This is the peer-reviewed version of the following article: Leifeld, Philip (2013): Reconceptualizing Major Policy Change in the Advocacy Coalition Framework: A Discourse Network Analysis of German Pension Politics. The Policy Studies Journal 41(1): 169-198, which has been published in final form at http://dx.doi.org/10.1111/psj.12007. This article may be used for non-commercial purposes in accordance with Wiley Terms and Conditions for Self-Archiving.

\title{
Reconceptualizing Major Policy Change in the Advocacy Coalition Framework: A Discourse Network Analysis of German Pension Politics
}

\author{
Philip Leifeld
}

\begin{abstract}
How does major policy change come about? This article identifies and rectifies weaknesses in the conceptualization of innovative policy change in the Advocacy Coalition Framework. In a case study of policy belief change preceding an innovative reform in the German subsystem of old-age security, important new aspects of major policy change are carved out. In particular, the analysis traces a transition from one single hegemonic advocacy coalition to another stable coalition with a transition phase between the two equilibria. The transition phase is characterized (a) by a bipolarization of policy beliefs in the subsystem and (b) by state actors with shifting coalition memberships due to policy learning across coalitions or due to executive turnover. Apparently, there are subsystems with specific characteristics (presumably redistributive rather than regulative subsystems) in which one hegemonic coalition is the default, or the "normal state". In these subsystems, polarization and shifting coalition memberships seem to interact to produce coalition turnover and major policy change. The case study is based on discourse network analysis, a combination of qualitative content analysis and social network analysis, which provides an intertemporal measurement of advocacy coalition realignment at the level of policy beliefs in a subsystem.
\end{abstract}

Keywords: Advocacy Coalition Framework, Discourse Network Analysis, Policy Change, Polarization, Pension Politics, Old-Age Security, Demographic Change, Germany, Policy Networks, Policy Debates, Political Discourse

The author wishes to thank Frank Kaiser, Volker Schneider, Christoph Engel, Karin Ingold, members of the workshop series "Networks and Time" at Columbia University, and four anonymous reviewers for helpful comments on earlier drafts, and the Max Planck International Research Network on Aging (MaxNetAging), the Max Planck Institute for Demographic Research and the Max Planck Institute for Research on Collective Goods for financial and scientific support. 


\section{Introduction}

How does major policy change come about? Existing evidence in line with the Advocacy Coalition Framework (ACF) suggests that policy subsystems are structured around competing advocacy coalitions (Sabatier 1998). They are stable for long time periods, often much more than a decade (Zafonte and Sabatier 2004; Jenkins-Smith et al. 1991). This equilibrium guarantees policy stability and is only interrupted when external perturbations cause coalition members to refine their internal belief systems significantly (Sabatier and Weible 2007: 193). When this happens, major policy change becomes likely.

Yet this perspective leaves important questions unanswered: what exactly happens when coalition members adjust their belief systems - do they leave their coalition and join the political opponent? How does the structure of a subsystem change when belief change occurs? Is there a transition phase, and what does it look like? Does the competition between two or more stable coalitions constitute the "normal state" of policy-making irrespective of institutional context across political systems? Or could this be a peculiarity of pluralist or other institutional contexts, and there are in fact subsystems where only one hegemonic coalition is the rule?

In this article, an empirical case study is presented which sheds light on these open questions. Using a methodological advancement based on a combination of social network analysis and qualitative data, the belief similarity networks of actors in the German policy subsystem of old-age security are mapped over time. In particular, I posit that hegemony of a single coalition may be the rule rather than the exception in some types of policy subsystems. In these cases, a polarization into competing coalitions and the shift back to a single coalition with new members and new beliefs necessarily occurs before major policy change can take place. This conflictual transition phase is guided by two interrelated processes: belief polarization and learning across coalitions.

The paper strives to achieve four goals: opening the black box and describing the processes predating major policy change; demonstrating how consensus and polarization may alternate to produce policy stability or change; discussing the relevance of the "discursive layer" of subsystem politics for policy-making; and the introduction of methodological tools which will enable researchers to tackle a host of new research questions centered around these themes.

The article is structured as follows: The second section briefly reviews the literature on the ACF and connects the overarching theme of policy change to related approaches in the public policy literature. The second and third sections also point out that our understanding of policy learning and policy change is still limited and suggest that new insights can be gained by analyzing the temporal pattern of subsystem change at the discursive level. To meet this challenge, a methodology called "discourse network analysis" is described in the fourth section. It draws on social network analysis and is capable of measuring belief change in subsystems over time. An original dataset on German pension politics is presented, which was compiled using the software Discourse Network Analyzer, and background information on the case study is provided. The next section presents the results of the empirical analysis, and the subsequent section carves out some observable mechanisms and reconnects these findings to the ACF. Finally, the conclusion proposes pathways for future research and recapitulates on the discourse network approach as a means to tackle these open questions. 


\section{Advocacy coalitions and major policy change}

As we know from the ACF, political actors in a policy subsystem can be classified into coalitions of competing policy beliefs (Sabatier 1998). They have complex belief systems at several layers of intensity and alterability (cf. Henry et al. 2011) and coordinate within but not across coalitions (Weible 2005; Ingold 2011). Advocacy coalitions are usually stable over time (for a review, see Zafonte and Sabatier 2004), and they are polarized particularly in conflictual subsystems (Jenkins-Smith et al. 1991). Administrative agencies have more moderate positions than interest groups and thus often act as policy brokers or intermediaries between coalitions (Sabatier 1998). Scientific evidence is frequently employed in order to back one's own policy positions (Sabatier 1987). New information or exogenous shocks have been identified as the main drivers of policy learning within and across coalitions, and policy learning has been found to cause policy change (Sabatier 1998).

In this perspective, the actual processes of policy learning and policy change largely remain a black box (cf. Mintrom and Vergari 1996; Nohrstedt 2010). Especially the very transition from one stable advocacy coalition structure to a new stable advocacy coalition structure has not been sufficiently explored within the ACF. Does one coalition simply discard previously held beliefs instantly upon receipt of new information and join the political opponent? Is the existence of two or more stable coalitions really the "normal state" of policy-making, or is the emergence of polarized coalitions merely a temporally confined piece in the puzzle of policy change?

Other scholars have pointed out that subsystems may be structured around a single hegemonic coalition instead of two or more competing coalitions. Baumgartner and Jones (1991), for example, argue that the "normal state" of politics is rather non-conflictual because one hegemonic coalition can clearly determine the course of political action. This centralized policy network structure is stable until previous "policy losers" are able to change the policy image and shift the venue of policy-making, leading to feedback loops and eventually culminating in a punctuation of the policy equilibrium. According to this theory, policy change is rare and, if it occurs, strong (cf. Jones and Baumgartner 2005). Similarly, Hall (1993) argues that dominant policy paradigms structure subsystems for long periods of time. When actors realize that various core aspects and more peripheral aspects of a policy lose their credibility, the policy paradigm is replaced by a new paradigm.

This contrast between the ACF and related theoretical frameworks discloses important questions: may there be two alternative types of equilibria in policy subsystems one of them characterized by multiple competing coalitions, and the other one characterized by transitions from one hegemonic coalition through a rewiring phase to another hegemonic coalition? Should this hold true, we must ask: what institutional, temporal or cultural factors can explain whether competition between coalitions is a cross-sectional or a temporal pattern?

A vague hint is provided by Sabatier and Weible (2007: 199f.), who allow for the possibility that coalitions may operate in different ways if one compares corporatist consensus democracies with majoritarian-pluralist polities. They concede that "the higher the degree of consensus required, the more incentive coalitions have to be inclusive (rather than exclusive), to seek compromise and share information with opponents, and generally to minimize devil shift" (Sabatier and Weible 2007: 200). However, the implications for subsystem structure are in principle uncertain. Sabatier and Weible (2007: 200) suggest 
that "advocacy coalitions will tend to have fewer actors, and the norms of compromise will create incentives for moderates to broker deals across coalitions." The analysis below sheds light on this question and adds a temporal perspective on subsystem change in a corporatist setting before major policy change takes place.

\section{The discursive layer of subsystem politics}

Advocacy coalitions are composed of two distinct "layers" which can be measured empirically: beliefs and coordination. The original version of the ACF focuses largely on the belief systems of political actors and how they structure policy subsystems (Sabatier 1987). Accordingly, early analyses of advocacy coalitions examined beliefs of actors rather than coordination among them over long time periods by means of content analysis (e.g., Jenkins-Smith et al. 1991). Following the proposition of Sabatier (1987: 664), "it seems preferable to allow the actors to indicate their belief systems (via questionnaires and content analysis of documents) and then empirically examine the extent to which these change over time."

Only after subsequent modifications of the ACF, coordination between actors in coalitions was established as the second layer of structures that can be measured empirically in policy subsystems: actors "both (a) share a set of normative and causal beliefs and (b) engage in a non-trivial degree of co-ordinated activity over time" (Sabatier 1998: 103). More recently, coordination has become a central interest of advocacy coalition scholars, and the policy network approach (Pappi and Henning 1998; Schneider 1992) and social network analysis are now frequently applied in order to delineate coalitions in terms of information exchange and other relations between actors (Ingold 2011; Lubell et al. 2012).

Belief systems, however, are still the primary theoretical factor that structures coalition membership and subsystems and which distinguishes the ACF from the vast literature on policy networks that has evolved since the early 1970s. Coordination is conditioned and structured by belief systems of actors (Sabatier 1998), and more recent analyses could confirm that both are indeed closely associated (Ingold 2011 and Weible 2010; but see Leifeld and Schneider 2012).

Moreover, while coordination may be an interesting feature of coalitions, questionnaires with retrospective questions about coalition structure would fail to generate any meaningful results due to recall errors, hindsight bias and similar problems (Finney 1981; Geweke and Martin 2002; Janson 1990; van der Vaart et al. 1995), especially when actors are asked to reconstruct historical relations that may have existed more than a decade ago. Unless repeated questionnaires are employed, content analysis still seems to be the only viable way of measuring advocacy coalitions over periods of a decade or more.

For these reasons, and in line with Jenkins-Smith et al. (1991), I propose an operationalization of the belief-related components of the ACF based on content analysis of newspaper articles. ${ }^{1}$ More specifically, I measure what Sabatier (1998: $\left.116 \mathrm{f}.\right)$ calls "policy core policy preferences" in his qualification of the Advocacy Coalition Framework the second most specific and most alterable normative type of policy beliefs (out of four

\footnotetext{
${ }^{1}$ Other kinds of archival data could have been used alternatively. For example, Fisher et al. (2013) extract issue stances of actors from testimonies of legislators and interest groups in the U.S. Congress. News media data presumably capture a wider variety of political actors while Congressional testimonies may be more confined to actors involved in the legislative process. On the other hand, media data may be more selective in favor of mediagenic actors. More research is required on how these different political arenas overlap in terms of their sets of actors.
} 
types: deep core beliefs, policy core beliefs, policy core policy preferences, and secondary aspects). They "are broad in scope (affecting virtually all members of the subsystem), involve very salient beliefs, and have been the source of long-term conflict" (Sabatier 1998: 117). These policy preferences are geared towards moving future policy-making in a subsystem into a general normative direction. Most importantly, however, they "constitute the principal 'glue' holding a coalition together" (Sabatier 1998: 117) and can thus directly serve to operationalize the most crucial aspect of advocacy coalitions: normative belief similarity regarding policy instruments.

The articulation of policy core policy preferences is a complex, relational phenomenon. Actors reveal their preferences in the media or other arenas and thus other actors feel encouraged to support them or reveal their opposition. As such, this articulation of normative beliefs can be subsumed under the more general notion of "discourse" (cf. Schmidt 2010) and can thus be understood as a "discursive layer" of subsystem politics.

In order to measure coalitions based on these data, some transformations are required. The following section briefly outlines the methodology of discourse network analysis, an approach which combines qualitative content analysis with social network analysis in order to visualize the development of coalitions over time. Social network analysis seems like a natural choice for modeling policy debates because political discourse is an inherently relational phenomenon. Discourse network analysis has been employed to study a political conflict about software patents in the European Union (Leifeld and Haunss 2012) and the formation of consensus around climate policy-making in the U.S. Congress (Fisher et al. 2013, 2012).

\section{The methodology of discourse network analysis}

With the advent of digital technology, full-text archives of newspapers, parliamentary testimony or other venues are readily available as a source of information. They fill a gap where elite interviews fail, as is the case in analyses of policy debates. Unfortunately, raw text data are unstructured and thus require an elaborate methodology to draw useful conclusions from them. For precisely this purpose, I created a free-to-use Java-based software called Discourse Network Analyzer in order to facilitate the qualitative coding process and the conversion of actors' statements into network data (Leifeld 2013; see http://www.philipleifeld.com). In this software, text data can be imported, statements of actors can be manually encoded, and the resulting actor or concept map can be exported as one out of several network types.

\subsection{Affiliation networks}

The following descriptive model of political discourse is adopted. There are political actors who make statements in the media (or whatever text source is used). A statement is a text portion where an actor utters his or her policy preferences in a positive or in a negative way. For example, an actor can either support or reject a policy instrument. For reasons of generality, policy instruments which are proposed by actors are called "concepts" in the following framework. A statement is thus a text portion containing (1) an actor, (2) a concept, and (3) the binary information about support or opposition.

More formally, let $A=\left\{a_{1}, a_{2} \cdots a_{m}\right\}$ be the set of actors in the data set, and let $C=\left\{c_{1}, c_{2} \cdots c_{n}\right\}$ denote the set of concepts in the data set. The coding procedure furthermore involves a dummy variable for agreement or disagreement of an actor with 
a concept. This set of relations can be defined as $R=\left\{r_{1}, r_{2} \cdots r_{l}\right\}$ with $l=2$ (for the two relations: agreement and disagreement). ${ }^{2}$ Since a particular emphasis is placed on the longitudinal analysis of discourse, the date of a statement is another critical aspect. Time is actually continuous, but for the sake of simplicity it will be modeled as being discrete in this context. Thus, $T=\left\{t_{1}, t_{2} \cdots t_{k}\right\}$ denotes the set of discrete time steps, for example the set of years in which statements are made.

The level of analysis is the statement. Whenever a statement occurs, a relation between an actor and a concept is inferred from this statement. This relation is modeled as an edge $e_{r, t}^{\text {aff }}(a, c) \in E_{r, t}^{\text {aff }}$ in a bipartite graph $G_{r, t}^{\text {aff }}$, where actors and concepts are modeled as vertices:

$$
G_{r, t}^{\mathrm{aff}}=\left(A, C, E_{r, t}^{\mathrm{aff}}\right)
$$

The aff superscript indicates that this is an affiliation network. There is one such bipartite graph for each agreement relation. It is possible to collapse the positive and the negative affiliation graph into a single multiplex network. One such graph can be constructed for each time slice $t$. As the graph is bipartite, it exhibits the property that only edges between actors and concepts are allowed, not within the set of actors or within the set of concepts:

$$
\left\{a, a^{\prime}\right\} \notin E_{r, t}^{\mathrm{aff}} \wedge\left\{c, c^{\prime}\right\} \notin E_{r, t}^{\mathrm{aff}}
$$

In this condition, $a$ denotes an actor and $a^{\prime}$ another actor; similarly, $c$ denotes a concept and $c^{\prime}$ an arbitrary second concept.

\subsection{Congruence networks}

Unfortunately, it is quite difficult to establish whether two actors actually exhibit high or low degrees of belief overlap, given the highly complex graphical representation of the affiliation network. One might not only be interested in how actors relate to concepts, but also in how far coalitions emerge from this structure. The basic idea is that the more concepts two actors agree (or both disagree) on, the more similar they are in terms of preferences or concepts in the discourse. Therefore, it is straightforward to move from a bipartite affiliation graph to an adjacency graph where actors are connected to other actors and where the edge weight between these actors represents the number of common concepts. The overall topology of the resulting congruence network can be used as a map of the discourse where clusters of actors represent advocacy coalitions. This is true because these preferences constitute the "stickiest glue" between coalitions (Sabatier and Weible 2007). The congruence network provides an intuitive way of conceptualizing and measuring coalitions at the ideational level (of course ignoring material aspects like information exchange relationships as analyzed by Leifeld and Schneider 2012).

Actor congruence networks are created as follows. Let $G_{t}^{\mathrm{a}}$ be an adjacency graph where the vertex set $A$ represents actors:

$$
G_{t}^{\mathrm{a}}=\left(A, E_{t}^{a}\right)
$$

with edges $e_{t} \in E\left(G_{t}^{\mathrm{a}}\right)$.

\footnotetext{
${ }^{2}$ The $l$ index is needed later in equation 6 to sum over the different relations. For this reason, agreement and disagreement are not merely hardcoded as $R=\left\{r_{1}, r_{2}\right\}$.
} 
Edges have a weight attached to them, such that $a$ denotes the source vertex of an edge, $a^{\prime}$ the target vertex and $w_{t}$ the weight of the edge between source and target. Actors do not have a subscript $t$ because the model assumes they are present in all time periods. Only the presence or absence of statements (or edges) may vary over time.

$$
\forall e_{t}: e_{t}=\left\{a, a^{\prime}, w_{t}\right\}
$$

$W_{t}$ is the set of weights, and $w_{t}\left(a, a^{\prime}\right) \in W_{t}$ denotes the edge weight between $a$ and $a^{\prime}$. Edge weights are computed as follows. In the affiliation graph of equation 1, a neighbor is an adjacent vertex of another vertex. Neighbors of concepts must be in the set of actors and vice-versa, as required by equation 2 . The set of neighbors of vertex $a$ in the affiliation network is denoted as $N_{G_{r, t}^{\text {aff }}}(a)$. It contains all concepts actor $a$ refers to in the affiliation matrix. Hence it is defined as the set of concepts that are incident with an edge containing $a$ as a source or target vertex. $E_{r, t}(a)$ denotes the set of edges incident with $a$.

$$
N_{G_{r, t}^{\mathrm{aff}}}(a):=C \in E_{r, t}^{\mathrm{aff}}(a)
$$

An edge weight is computed by considering neighbors in the affiliation network:

$$
w_{t}\left(a, a^{\prime}\right)=\sum_{r=1}^{l}\left|N_{G_{r, t}^{\mathrm{aff}}}(a) \cap N_{G_{r, t}^{\mathrm{aff}}}\left(a^{\prime}\right)\right|
$$

In equation 6 , the edge weight between $a$ and $a^{\prime}$ is determined by computing the intersection of their sets of neighbors and counting the elements of this intersection. This is done for both relations (agreement and disagreement), and both counts are summed up. In other words, the edge weight between two actors is the number of concepts they both refer to in the same (i. e., positive or negative) way.

The interpretation is straightforward: the edge weight can be interpreted as a measure of similarity in the discourse. The more similar the policy preferences of two actors, the higher their edge weight. Accordingly, cohesive subgroups in the graph can be interpreted as coalitions while sparse connections between these clusters reflect policy belief divergence.

\subsection{Threshold values}

In a visual inspection of the resulting network diagrams, threshold values can be imposed: in order to avoid wrong inference due to coding errors or random behavior/noise of actors concerning their statements, the lowest edge weights can be ignored during the analysis by imposing a threshold value on the edge weight. The cut-off value can be increased in a step-wise fashion until the structure of the discourse network becomes visible. There is essentially a trade-off between allowing too much noise (and therefore drowning in too much artificial complexity) and filtering out too much relevant information by setting the threshold value too high. The optimal threshold value is usually determined in an explorative way because the degree of noise critically depends on the size of the time slice, the number of concepts and other factors which vary between empirical applications. Such a threshold value, however, is only required for the visual inspection of the network but not for subgroup analyses based on structural similarity, which are also presented below. 


\subsection{The normalization of edge weights}

Quite obviously, actors who make more statements than other actors are likely to be central in the resulting congruence network. This affects particularly governmental actors who are officially in charge of dealing with a problem, for example the relevant governmental agency. One way to correct for this potential bias is to employ a normalization (for more details and a discussion, see Leifeld 2011). The normalization of an edge weight, $\Phi\left(w_{t}\right)$, is the edge weight divided by the average number of concepts both actors refer to in the affiliation network - either in a positive or in a negative way (hence the union of the two sets of neighbors for the distinct relations):

$$
\Phi\left(w_{t}\left(a, a^{\prime}\right)\right)=\frac{w_{t}\left(a, a^{\prime}\right)}{\frac{1}{2}\left(\left|N_{G_{r=1, t}^{\text {aff }}}(a) \cup N_{G_{r=2, t}^{\text {aff }}}(a)\right|+\left|N_{G_{r=1, t}^{\text {aff }}}\left(a^{\prime}\right) \cup N_{G_{r=2, t}^{\text {aff }}}\left(a^{\prime}\right)\right|\right)}
$$

\subsection{Additional specifications and matrix notation}

Analogous methods can be employed to create a concept congruence network, a conflict network and dynamic discourse networks. As these network types are not required for the specific analysis presented in this article, the reader is referred to the detailed discussion in Leifeld (2011).

There are two mathematical foundations of social network analysis: graph theory and matrix algebra. The basic model described here was presented using graph theory, but the same logic can be expressed in matrix notation. For the sake of clarity, the basic model is described in matrix notation in appendix $\mathrm{A}$.

\section{The dataset}

A case study about German pension politics is presented below. Using the software Discourse Network Analyzer, 7,249 statements of political actors between January 1993 and May 2001 were encoded. This time period roughly covers the decade before the Riester reform, an instance of major policy change in this subsystem. The law was passed in May 2001.

\subsection{The coding procedure}

The dataset was created in three steps. First, the source was selected. Three newspapers were available as digital full-text archives. Two of them are known to be politically moderate. Both newspapers correspond to the "quality press" criterion (Barranco and Wisler 1999; Koopmans 1996; Kriesi 1995): they have a wide circulation and are politically moderate and reputable. In order to avoid potential problems with double coverage of events, only one of these newspapers was eventually selected: Frankfurter Allgemeine Zeitung (FAZ). Media bias may be a minor issue for a cross-sectional analysis. Unless the newspaper changes its political orientation over time, however, the potential bias should be constant and longitudinal changes in the discursive structure should still be observable.

Second, the population of articles had to be defined. Only the "politics" and "business" section of the newspaper were considered; feuilleton pages and other sections were 
excluded because their journalistic style was more normative and arguments were often implied rather than made explicit. The search term "*rente*" (the German word for "pension" surrounded by wildcards) was used to identify 1,879 potentially relevant articles.

Third, all articles were read, and their contents were manually encoded. Whenever a political actor revealed his policy preferences about a policy instrument related to the pension system, this was coded as a statement (according to the definition given above). ${ }^{3}$ Individuals and organizations were considered simultaneously. In the final analysis, only statements made by organizational actors were retained because important persons without an organizational affiliation were not present. If an actor or a concept was not already in the dataset, it was subsequently added to the list. While the coding was mainly inductive (with a certain number of deductively pre-identified solution concepts from the theoretical literature), a multi-pass coding strategy was employed, i.e., the coder had to navigate back and forth between the statements in order to ensure a consistent way of coding.

A single researcher encoded the articles, and a second individual checked the codes of the other researcher but did not code any data independently. This coding procedure (1) increased the reliability compared to a single-coder strategy and (2) was less laborand hence cost-intensive than independent coding of the same articles by two separate individuals. While intercoder reliability could not be explicitly checked with this coding procedure, other measures were taken to ensure a high quality of the dataset: as mentioned above, all codes were reviewed by a second researcher, and in cases of disagreement, codes were discussed and a consensual solution was found. Moreover, an algorithm was implemented into the software which can identify self-contradictions of actors over time (that is, an actor refers to a concept in a positive way somewhere and in a negative way somewhere else). This information was used to detect and fix inconsistencies. In most cases, however, statements were made in an unambiguous way. Finally, a full-text search based on regular expressions was employed to find statements which had been previously overlooked. All of these measures indicated that the coding was very consistent. The final dataset contains 7,249 statements of 246 organizations and/or 461 persons about 68 concepts from 1,879 articles between 1993 and $2001 .^{4}$

\subsection{Classification of actors}

Actor congruence networks were exported from this dataset as described in the previous section. Visualization of the networks was done using the software ${ }^{\mathrm{V}} \mathrm{i} \mathrm{s}_{\mathrm{n}} \mathrm{n}_{\mathrm{e}}$ (Brandes and Wagner 2004). Actors in the dataset were classified into seven categories: social actors like trade unions, senior citizens' interest groups, employees' party organizations or other social interest groups (red color in the following analysis); liberal actors like industry or employers' associations, managers' interest groups and think tanks with a market-liberal mission statement ( yellow color); decision-makers like governmental actors, political

\footnotetext{
${ }^{3}$ To understand how statements were encoded, consider the following fictional example: "The number of immigrants does not affect the old-age ratio. We would have to invite 175 million people to compensate for demographic change. Increasing women's share in the labor market to generate additional contributions should be our primary goal." - In this case, beside the name of the person who makes the statement and his or her organizational affiliation, the following codes would be attached to the text portion: "immigration"-"no", and "increase female labor participation"-"yes".

${ }^{4} \mathrm{~A}$ list of all normative concepts as well as the list of actors and their abbreviations can be found in a supplementary online appendix at http://dx.doi.org/10.1111/psj.12007.
} 
parties and state agencies (gray color ); young people's interest groups and party organizations (magenta color); financial actors like banks, insurance companies and their interest groups and think tanks (blue color); scientific organizations like universities; and "other" organizations which could not be classified into any of the previous categories (black color).

As Sabatier (1987) argues, scientific evidence is usually employed by advocacy coalitions to back up and defend their claims. Scientific organizations would thus be scattered across all coalitions. Yet, one important aspect of the analysis is to understand which type of actor belongs to which coalition. Mapping scientific organizations along with the other actors in a network diagram would rather make the subsystem structure more complex and would render this task more difficult. For this reason, they are omitted in the network visualizations, which are part of the following analysis. However, they are included as green nodes in the cluster analyses presented below.

\section{Case study background}

Demographic change poses serious challenges to established pension systems around the globe. In coordinated market economies and beyond, an increasing number of senior citizens must be sustained by a shrinking population of young people who pay contributions into the pension system.

\subsection{Characteristics of the policy subsystem}

In Germany, the old-age dependency ratio, which measures the number of citizens aged 65 and over divided by those aged 15 to 64, is likely to rise until it reaches its peak around the year 2035 (cf. Berkel et al. 2004). Taking no action would automatically increase the contribution rate, part of the non-wage labor costs in Germany, which are jointly financed by employers and employees. Some argue that this strong additional burden may be so extreme that consumption is jeopardized, leading to an eventual "collapse" of the social security system (Birg 2002; Graf von der Schulenburg and Wähling 1997).

Against this background, there is pressure for reform to make pension systems more sustainable. There are numerous alternatives and propositions of political actors and economists as to how this can be achieved, but there is no consensus between these actors what may be the most appropriate solution. The subsystem of pension politics can thus be characterized as an institutionalized subsystem with demographic change as a relatively stable parameter that provides reform incentives to actors. There is no consensus, however, what kind of reform would be appropriate.

\subsection{The 2001 Riester reform as a case of major policy change}

In the German case, a path-breaking reform was passed in May 2001: the Riester reform (named after then-minister Riester). It replaced the public pay-as-you-go pension system by a multipillar system with private capital-funded elements (for a rough description, see Börsch-Supan and Wilke 2003). There is scholarly consensus that - despite minor reforms throughout the last three decades - this was the only case of major policy change (Lamping and Rüb 2004; Trampusch 2008; Schmähl 2000; Wehlau 2009) because it introduced new elements at all levels of the inherent belief system of the policy, from deep 
core to secondary aspects ("third-order change" according to Hall 1993). The reform was a "direction setting law" which introduced only minor changes at first glance but "puts pension policy on an irreversible track that will constrain all future governments and thus determine all future pensions laws" (Lamping and Rüb 2004).

\subsection{Competing reform options and policy preferences}

While the reform might seem at first glance like a logical next step which could effectively counter the threat of population aging, the situation was and still is in fact considerably less clear. The easiest but least appropriate explanation stems from a functionalist view: privatization and capital cover elements had to be introduced because there was the imminent threat of demographic change. This explanation is flawed because many alternative measures were discussed, whether they would be able to solve the problem or not. There are four arguments why privatization was not necessary: (1) capital-cover elements might have been introduced within the public pension system instead of privatizing the pension system; (2) the shift to a (partial) capital-cover system implies severe transaction costs and intergenerational inequalities (Breyer 2000); (3) it is not clear to what extent population aging as a dynamic phenomenon would have self-regulated the problem after several decades; and (4) alternative pathways were equally feasible.

In the light of this complexity, politicians and scientists argued in multiple directions. For the time period between 1993 and 2001, 68 distinct solution concepts addressing the pension gap could be identified in the political debate. ${ }^{5}$ Besides privatizing the system in order to yield higher returns and besides partly decoupling contributors from annuitants by introducing a capital cover system, the following reform options or policy instruments ranged among the more popular solution concepts: fertility incentives in order to decrease the old-age dependency ratio (like parenting periods or tying the contribution or pension level to the number of children someone has "produced"); immigration; capital cover elements within the public pension system; flat rate pensions; more "gender equality" (that is, lowering the old-age dependency ratio by having more female employees and thus contributors); simply increasing the level of contributions; cutting the pension level; tying the pension equation to the demographic or economic development; raising the retirement age; including civil servants, self-employed people, low-income earners and other groups into the pension system; increasing subsidies from the general tax budget or replacing contributions completely; and removing intra-generative redistribution as non-insurance elements from the PAYG system.

In other words, there was a large set of feasible policy instruments two of which survived the selection process of policy-makers. Why, then, was the pension system partly privatized, and why did this happen in 2001? Moreover, how were the competing advocacy coalitions around these policy preferences structured, and how would they change over time?

\subsection{Uncertainty, complexity, and why policy beliefs mattered}

There was considerable scientific uncertainty about demographic trends (Goldstein et al. 2009; Lesthaeghe and Willems 1999; Sobotka 2004; Sobotka et al. 2011) and their underlying mechanisms. The literature knows at least ten different fertility theories, ranging

\footnotetext{
${ }^{5} \mathrm{~A}$ list of these concepts is provided in a supplementary online appendix at http://dx. doi .org/10. $1111 / \mathrm{psj} .12007$.
} 
from economic modernization, culture, social networks, or neoclassic economic theory to the rise of contraceptive technology, inter-generational wealth flows, decreasing sperm quality at the population level, or evolutionary biology. Similarly, there is considerable scientific disagreement about future trends of mortality, with some scholars arguing that there is an upper bound to life expectancy and others arguing that life expectancy may continue to increase linearly by up to 2.5 years per decade (Ney 2000; Oeppen and Vaupel 2002; Scherbov and Sanderson 2010). This technical complexity rendered clear policy advice nearly impossible.

In addition, there are feedback loops which render the system potentially unlearnable. Demographic change is a dynamic phenomenon. It gets worse until approximately 2035 and may improve afterwards. This may be the case because population aging is jointly caused by low mortality and low fertility. Once the baby-boomers die out, they are replaced by much smaller cohort sizes, which is likely to affect the old-age dependency ratio in a positive way. If it is possible to survive the peak in 2035 by implementing some of the other proposed policy instruments, their proponents argue, demography will self-regulate the system, and the remaining rise in the contribution rate is so low that it can be compensated by tax subsidies, by getting rid of non-insurance elements, or by increasing the number of contributors. Similar arguments apply to some of the other solution concepts that have been put forth: fertility incentives may increase the number of additional contributors in the medium run but may also increase the number of pensioners in the long run, once these children become senior citizens themselves.

In the light of this uncertainty, complexity, and feedback loops, the choice of the appropriate course of action largely depended on policy beliefs (Sabatier 1998) rather than objective measurement, and political discourse became the main arena for determining what actions to take and what policy beliefs to adopt (cf. Heclo 1978; Sabatier 1987).

\subsection{Belief change as a driving factor in the subsystem}

Observers note that pension policy-making until the mid-1990s was determined by the socalled "pension consensus", a hegemonic group of governmental organizations, political parties and trade and industry associations whose dominant policy beliefs (Sabatier 1998) and instrument choices were not challenged in the political sphere. This pension consensus eroded in the mid-1990s (Wehlau 2009: 93) because the number of divergent, competing scientific conclusions on the pension problem increased substantially (Wehlau 2009: 260). As a result, "there no longer is one pension truth, but a choice of several approaches to understanding the pension issue: what one chooses to believe now depends on where one stands" (Ney 2001: 34). Wehlau (2009: $259 \mathrm{ff}$.) considers the increasing activities of the financial sector in the public discourse as the cause of this development: banks, insurance companies, and their associations (co-) founded think tanks and research institutes like DIA and MEA as well as internal research departments like Deutsche Bank Research, and they made contracts with a number of previously independent researchers. This is in line with the hypothesis of Sabatier (1987) that competing advocacy coalitions use policy analyses and scientific expertise in order to grant credibility to their claims in the public sphere. The result was a newly emerging diversity of views on the future of the pension system, and eventually a diffusion of the multi-pillar idea from the financial sector, science and pseudo-science to voters and decision-makers. Explanations for the increasing involvement of financial actors and the changing discourse range from electoral change (Lamping and Rüb 2004) over within-party politics (Trampusch 2008; Wehlau 2009) or 
changing responsibilities of goverment departments (Wehlau 2009) to the substitution of executives in agencies or advisory committees.

Many observers note the important role that ideas, frame shifts and discursive turnover played in this process (Hinrichs 2004; Schulze and Jochem 2007; Ney 2001) or in German welfare state politics in general (Schmidt 2002). They attribute the policy change in 2001 to changes in advocacy coalitions, dominant beliefs and discursive contagion. Yet their accounts are rarely based on systematic empirical evidence and can be better described as instances of theory-building. What they have in common is that they hypothesize a) an erosion of the previously dominant advocacy coalition somewhere in the mid- or late 1990s, b) the introduction of new ideas or solution concepts into the political discourse, and c) an increased participation of actors from the financial sector in the debate, as the drivers of the policy change that can be observed in 2001. The analysis below will therefore fill this gap and a) provide this systematic empirical evidence, b) quantify precisely when and how the pension consensus eroded, and c) show what kind of advocacy coalition structure emerged in the aftermath of this erosion, what it looks like, and why it was conducive to policy change.

\section{The transition of the coalition structure}

As set out in the description of the case study background, the pension reform literature makes the following three-step prediction: in the first stage, there is a powerful and closed advocacy coalition with a large constituency until the mid-1990s. Their views are hardly challenged. In the second stage, after 1996, the coalition slowly erodes due to contradictory evidence and new actors from the financial sector, who make claims about the lack of sustainability in the statutory pension system. Consequently, the proponents of a paradigm shift gain a larger constituency. The political discourse becomes bipolar, with more and more actors leaving the previously dominant advocacy coalition and joining the proponents of change. In the third stage, after the 1998 election, the old coalition vanishes completely. The insurgent advocacy coalition has successfully installed a new policy belief system, and the discourse becomes unipolar or centralized again, with the pro-privatization advocacy coalition becoming the new hegemonic coalition. This gives leeway for a pension reform introducing a paradigm shift, as intended by the financial sector.

\subsection{Three stages: hegemony, polarization, and erosion}

In order to test whether these claims are justified, a cluster analysis of aggregated affiliation networks (see methodology section) is conducted for the three critical time periods separately. Figure 1 shows the dendrogram of the first time period. There are two clusters, but concluding from the agglomeration height, the separation between the clusters is not particularly strong. The group on the left contains most important actors which are classified as members of the pension consensus by the literature. The subgroup on the right contains some other members of the pension consensus like the peak trade association DGB, some industry associations (BDI, ZDH, BDS, ULA, DIHT) and some financial organizations (DVAG, DB, VLVU). The fact that DGB is among the second group supports the claim that the separation between the two clusters is not very strong. In general, the pension consensus advocacy coalition is clearly dominant. 


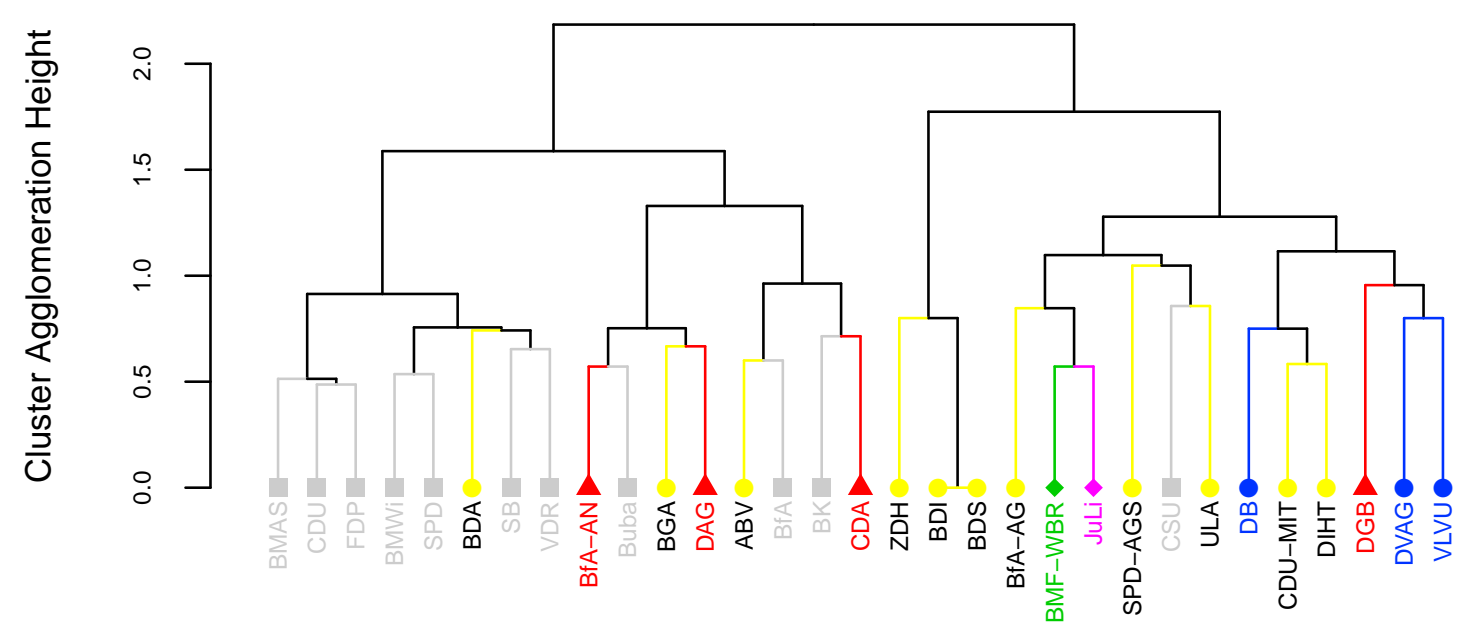

Note: Agglomerative hierarchical cluster analysis of the aggregated affiliation network; Ward's optimization; Jaccard distances; only actors with more than two statements are preserved.

Node colors and shapes: red triangles denote social actors; yellow circles denote liberal actors; blue circles denote actors from the financial market; magenta diamonds denote young people's organizations; green diamonds denote scientific organizations; gray rectangles denote governmental actors and parties; black rectangles denote other actors.

Figure 1: First stage, January 1, 1993 - December 31, 1995.

The second time period is depicted in Figure 2. Indeed, the coalition of system change proponents grows as large as the previously hegemonic advocacy coalition. A variety of financial organizations (DB, BVI, GDV, AGV, Dresdner Bank, etc.) challenges the traditional policy paradigm. The subsystem is extremely bipolar. There are some details which can be observed beyond the predictions of the literature: numerous social actors start to support the pension consensus in order to avert the imminent threat of privatization, among them VdK, SoVD, the churches, and several trade unions. Furthermore, and against the background of German corporatism, most major industry associations support the status-quo-oriented coalition (BDA, DIHT, ZDH). In this stage of the political process, the two advocacy coalitions show the highest internal congruence and the smallest overlap between the two coalitions.

In line with the conjectures, the pro-system-change advocacy coalition supersedes the previously hegemonic status-quo-oriented coalition in the third stage (Figure 3). It grows much larger than the traditional advocacy coalition, has a clearly defined and congruent core (the actors between Ludwig-Erhard-Stiftung and BMF), and the constituency now includes the subgroup of industry associations previously supporting the PAYG coalition (BDA, DIHT, etc.). What is more, two critical governmental actors, BMF and BMWi, have left the PAYG coalition and joined the capital cover proponents. Likewise, the Social Advisory Council has, due to personnel turnover, joined this coalition. The new structure of the discourse after the 1998 election essentially entails a hegemonic pro-system-change coalition composed of financial interests, industry interests and parts of the government (BMF, BMWi) against a shrinking advocacy coalition of social interests, members of the large parties, and parts of the government (BK and BMAS). The 2001 Riester reform is thus no longer surprising, given the changes at the belief layer of the subsystem which were already initiated in the mid-1990s by introducing divergent views on optimal policy design into the pension discourse. 


\section{Cluster Agglomeration Height}

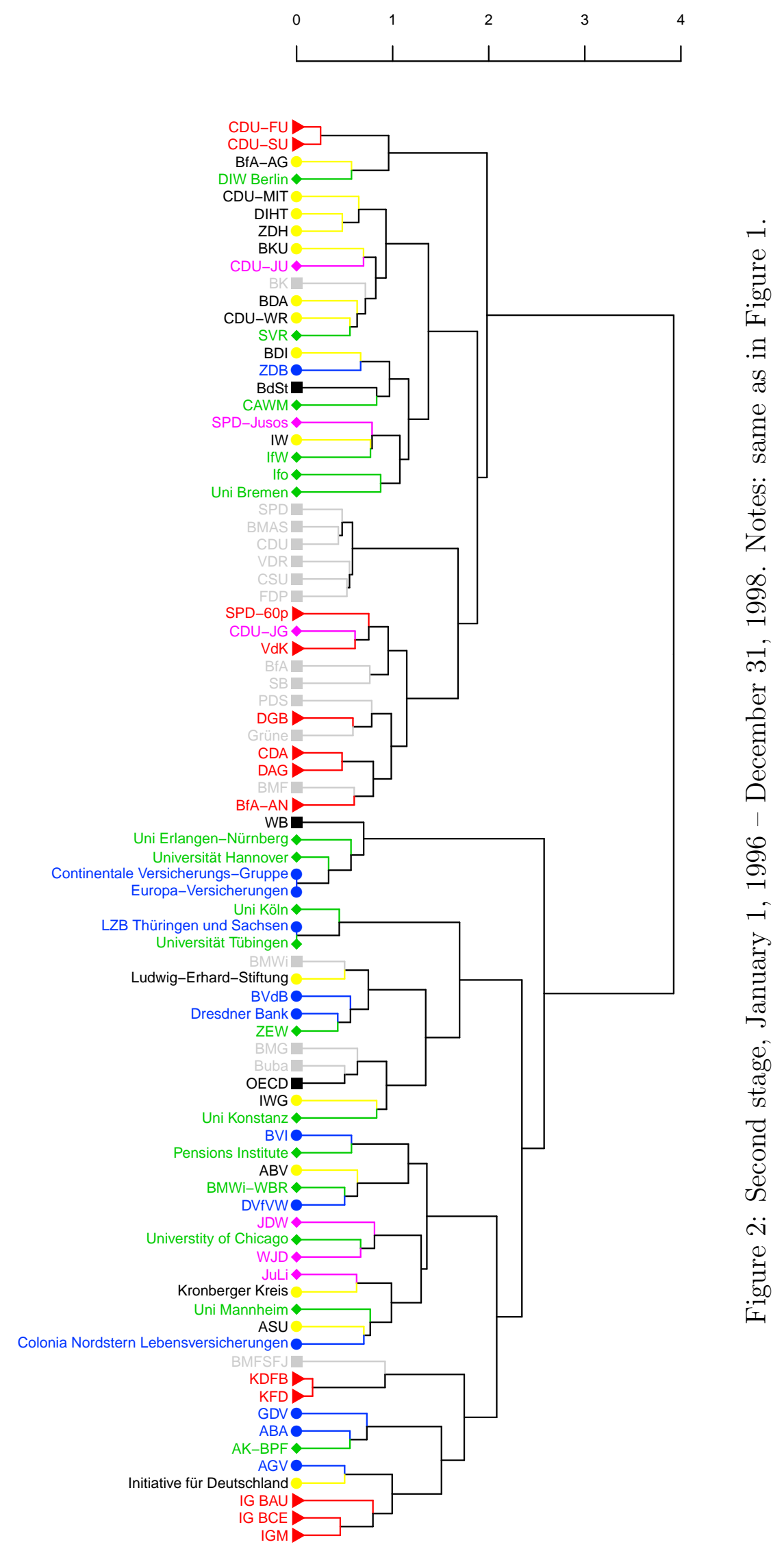


Cluster Agglomeration Height

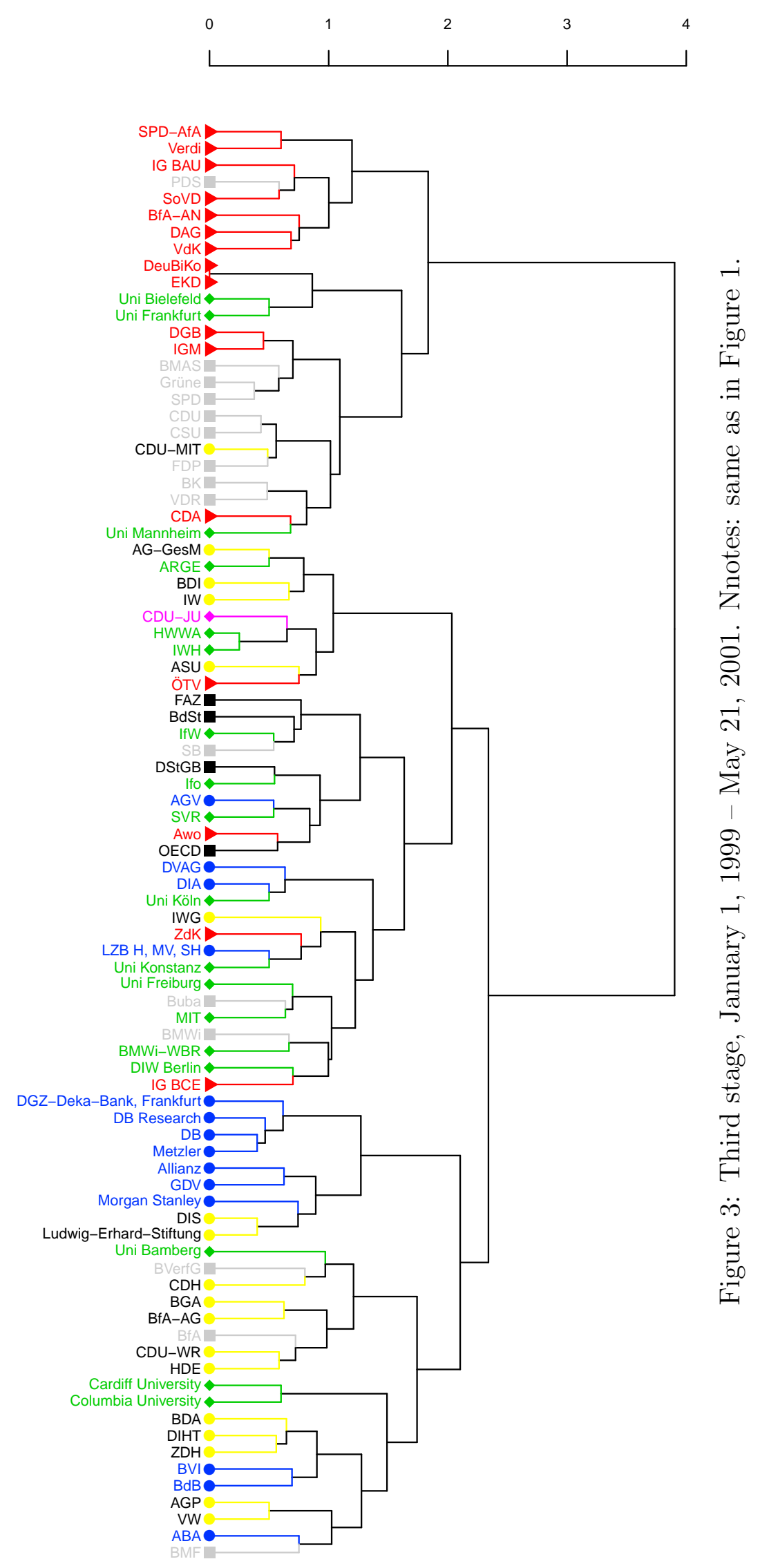




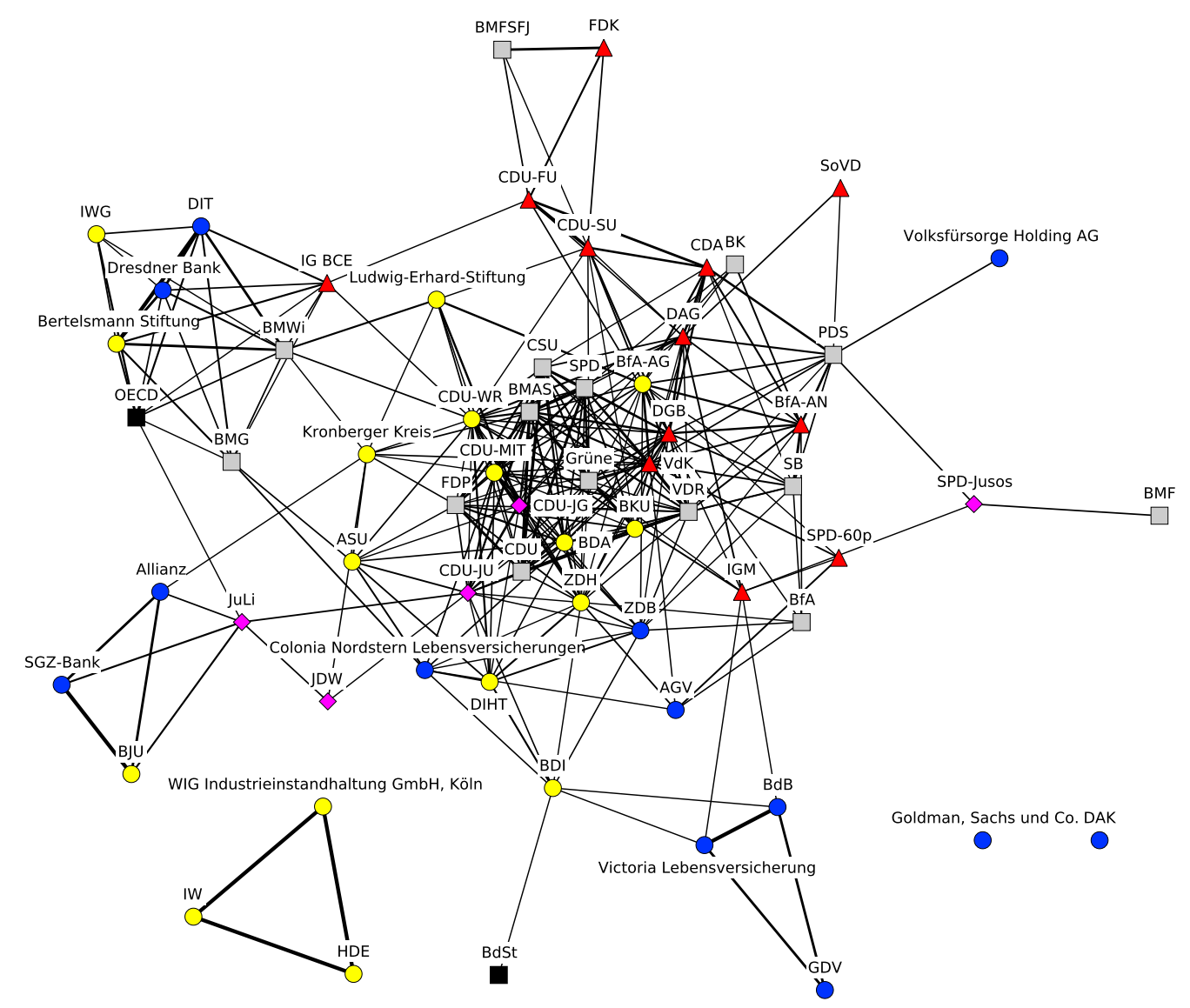

Notes: Edge width visualizes the strength of association. The graph layout is based on a stress minimization (MDS) of graph-theoretic distances (Brandes and Pich 2009) as implemented in the "quick layout" in vis ne $_{\text {(Brandes and Wagner }}$ 2004).

Node colors and shapes: red triangles denote social actors; yellow circles denote liberal actors; blue circles denote actors from the financial market; magenta diamonds denote young people's organizations; green diamonds denote scientific organizations; gray rectangles denote governmental actors and parties; black rectangles denote other actors.

Figure 4: Normalized actor congruence network in $1997(\Phi(w) \geq 0.31)$.

There is yet one puzzle to solve. How can a reform be passed if the relevant veto players (Tsebelis 1995) are still members of the shrinking, but still existing status-quo-oriented coalition? In fact, the major parties are partisan veto players: the social-democratic party SPD and the Green party as members of the government coalition, and the ChristianDemocrats CDU/CSU as partisan veto players in the Bundesrat, the second parliamentary chamber. Moreover, the ministry in charge for pensions (BMAS) cannot be easily superseded.

I argue that it is necessary to scale down to smaller time units in order to make the relevant changes visible (in the remainder of this section). Figures 4 to 7 show annual time slices of the normalized actor congruence network between 1997 and 2001. The visualization of the year 1999 is skipped because it looks similar to the diagrams of the surrounding years 1998 and 2000. Threshold values are set individually as to maximize the clarity of the network structure. In the network visualizations, the coordinates of vertices and the spatial distance between nodes cannot be interpreted in a meaningful way. The conclusions are solely drawn on the basis of the interconnectedness of the 


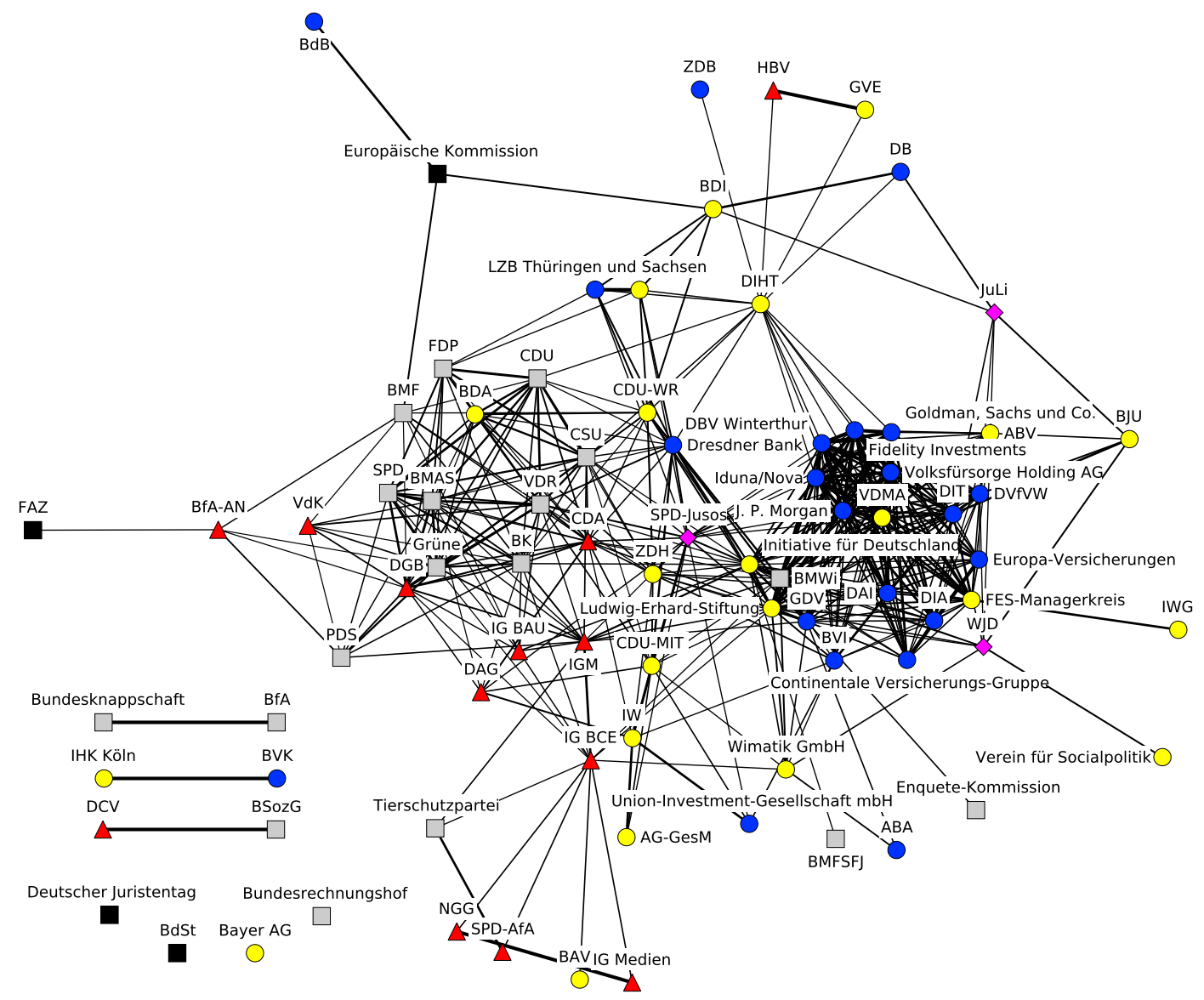

Figure 5: Normalized actor congruence network in $1998(\Phi(w) \geq 0.29)$. Notes: same as in Figure 4.

nodes. As described in the methodology section, the interpretation is straightforward: the strength of a tie between two actors reflects their normalized belief congruence. Clusters of interconnected actors can be interpreted as advocacy coalitions because the latter are made up of actors with overlapping policy core policy preferences (Sabatier 1998: 117).

\subsection{The status quo in 1997}

In 1997 (Figure 4), the extended status-quo-oriented coalition aligns with social interests, while the system-change advocacy coalition does not exist yet. There is already a substantial number of financial (blue) actors, but they emphasize different concepts rather than standing united in promoting system change and privatization. They are virtually scattering all around the dominant advocacy coalition. In this early stage, the Federal Ministry for the Economy (BMWi) aligns with liberal actors and industry interests and does not show any overlap with the pension consensus.

The broad consensus about the future directions of pension policy is clearly visible. In line with Sabatier (1998), however, there are two wings within this large advocacy coalition which follow the classic corporatist labor-capital cleavage line (denoted by the yellow nodes clustering south-west of the majority of state actors and the red nodes which are located predominantly north-east) and which have somewhat fuzzy borders and considerable overlap with each other. According to Sabatier (1998), this may be a typical feature of subsystems in corporatist regimes. He also notes that in these kinds 


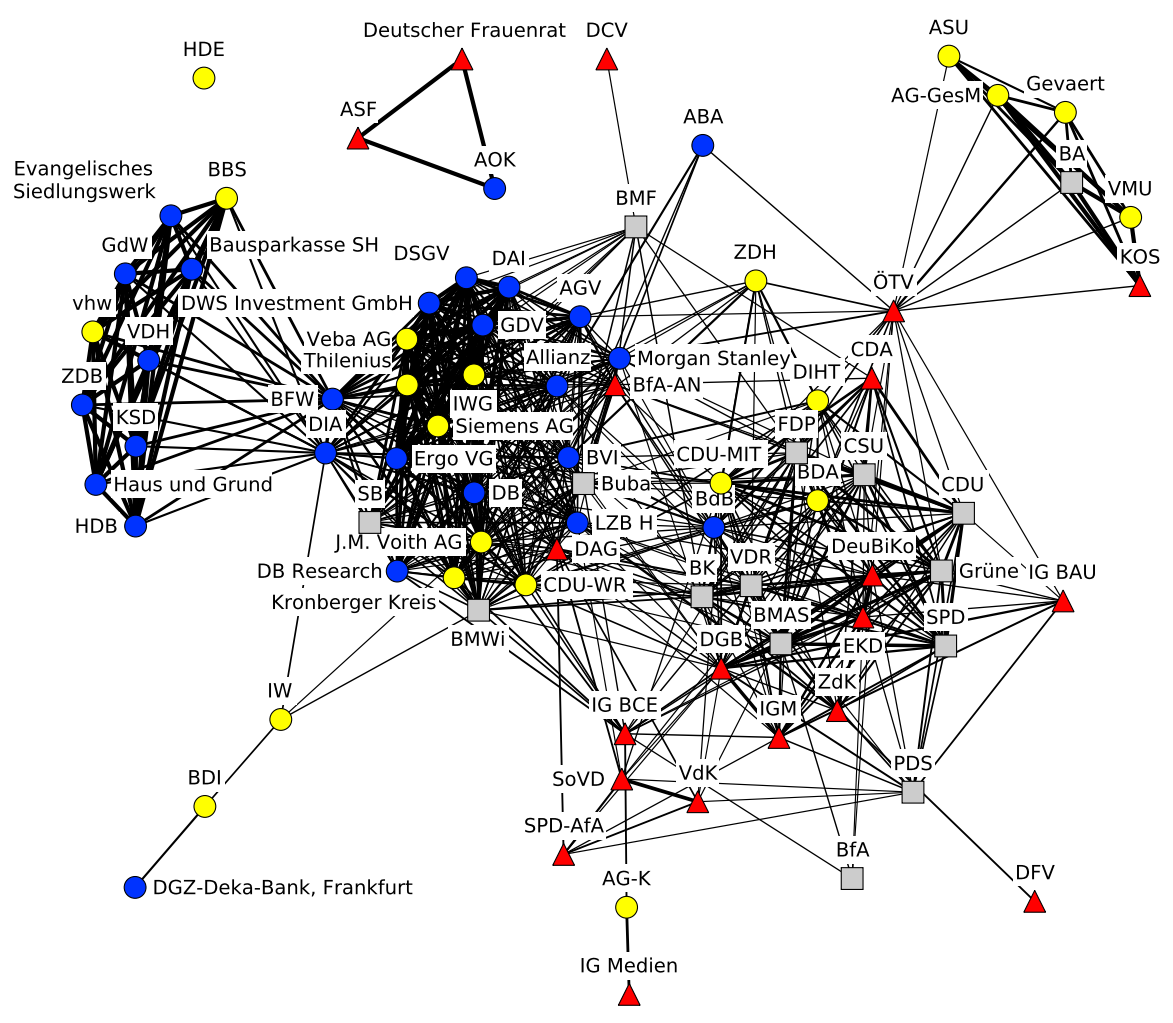

Figure 6: Normalized actor congruence network in $2000(\Phi(w) \geq 0.27)$. Notes: same as in Figure 4.

of subsystems, governmental actors assume strong intermediary roles as policy brokers. The conjecture can be confirmed here because governmental actors are predominantly located between the two camps.

\subsection{Polarization between 1998 and 2000}

In 1998 (Figure 5), the year of the election, the financial actors are suddenly very united in their claims. The bipolar structure with the pension consensus on one side and the financial sector on the other side emerges. The BMWi is now positioned within the financial bloc and a number of liberal actors. The parties and governmental actors align with the social actors, as before. However, a distinction between the two subcoalitions is slightly visible, with social actors consistently being located south of the governmental actors and parties.

In the year 2000, polarization reaches its peak. There are numerous ties within each advocacy coalition, and between-block density is very low. BMF, BMWi, and SB have joined the system change coalition. The government is thus divided over the pension question. Some other actors previously known as being rather social also join the new advocacy coalition. Among them are DAG, a major trade union, and the employees' wing of the BfA. The hegemony of the status-quo-defending advocacy coalition fades away, and some early adopters switch from one coalition to the other in 2000. These observations indicate that transitions between subsystem equilibria are not only accompanied by a belief polarization, but also by early adopters who leave their coalition and adopt the beliefs of the former opponent. This development leads to an erosion of the pension consensus in late 2000 and early 2001. 


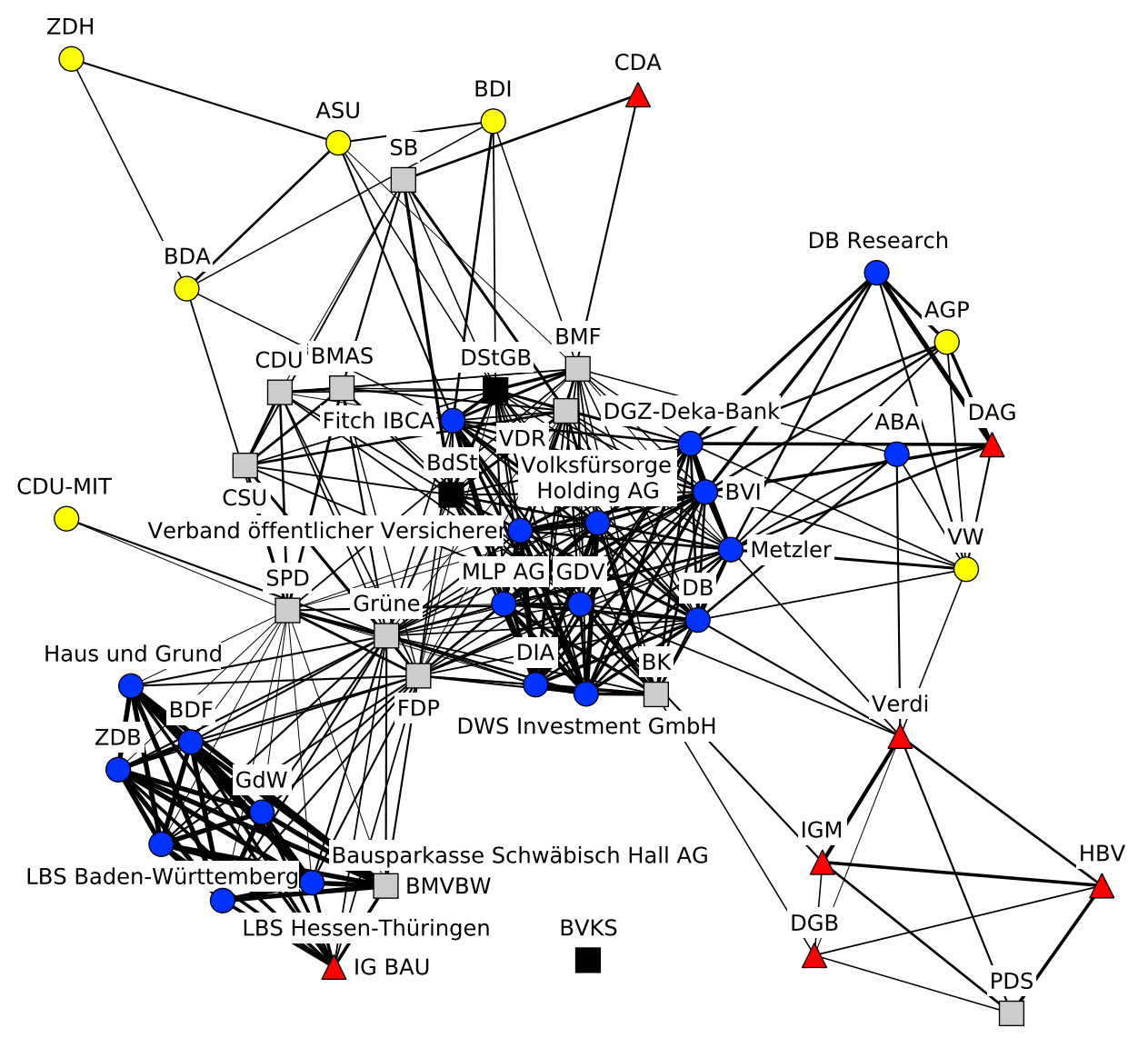

Figure 7: Normalized actor congruence network between January and May $2001(\Phi(w) \geq$ 0.23). Notes: same as in Figure 4.

\subsection{Dissolution of the formerly hegemonic coalition and insti- tutionalization of the new advocacy coalition}

Figure 7 shows the structure of the discourse between January and May 2001. The status-quo-oriented coalition has broken apart and is now situated at the margin of the new dominant privatization coalition, in some cases even bridging the housing and the insurance wing of the system change coalition. The chancellor (BK) has left his original coalition completely and joins the insurance cluster. Similarly, the association of the German statutory pension insurance scheme (VDR) joins the financial coalition and abandons its discursive ties to other governmental actors almost completely. Surprisingly, even the social actors are now dispersed all around the new dominant coalition. At the lower end, a small clique of social actors connects both to the chancellor and to the financial sector. Other social actors reside at various locations in the discourse (CDA, DAG, IG BAU); they are largely disconnected from the governmental actors with whom they used to share many basic premises of how the pension system should be designed.

\subsection{Significance for the pension reform literature}

How do these observations fit into previous accounts of German pension politics? Besides providing further evidence for the dominance of the newly established coalition right before the Riester reform was adopted, the main conclusion from these observations is 
that core decision-makers and veto players like the chancellor, the major parties, and the relevant federal ministries switched from their old coalition to the newly established coalition and thus gave leeway to the reform. A clear pattern of structural change at the level of policy preferences could be identified prior to the reform in 2001: a single hegemonic advocacy coalition until 1997, the emergence of a second advocacy coalition from 1998 onwards, a strong bipolarization of the discourse with an increasing number of critical political actors leaving their old coalition due to credibility problems of the old paradigm, and a complete erosion of the old coalition and attachment of their members to the new hegemonic advocacy coalition. This constitutes a shift from one normal state of policy-making until 1997 to a new normal state of policy-making after 2000, with a polarization phase in the meantime. Only after this process was finished, the reform was adopted. This lends new credibility to the argument that changes in the political discourse led to the reform and specifies clearly how and when these changes came about.

\section{Reconnecting the findings to the ACF}

A clear transition pattern between a single hegemonic advocacy coalition until 1997 and another hegemonic advocacy coalition from 2001 on can be be identified in the case study. Between these equilibria, there is a transition phase in which both coalitions co-exist and the subsystem becomes more and more polarized.

\subsection{Early adopters and learning across coalitions}

Once polarization has taken off, the erosion of the old coalition starts with some early adopters who leave their old coalition and join the political opponent. These are usually agencies or decision-makers rather than vested interest groups. This process resembles a bandwagon effect (Nadeau et al. 1993). The reason for this behavior may be manifold: in some cases outlined above, the directors or heads of an organization were replaced indirectly by members of the new coalition (SB, BMF); in other cases, policy learning across coalitions due to the discursive activity of the financial sector coalition may explain this shift (BfA-AN, DAG). In any case, these changing coalition memberships lent more credibility to the claims of the newly established coalition and presumably contributed to the erosion of the pension consensus coalition. Both processes - polarization and learning - interacted and had a disintegrating effect on the belief system inherent in the status-quo-oriented coalition. These results have implications for the ACF.

\subsection{A single hegemonic coalition}

Normal policy-making in the case study under scrutiny seems to be determined by a single hegemonic advocacy coalition rather than a competition between two or more coalitions. Such a competition can only be found in the relatively short transition phase between two subsystem equilibria or "normal states" of policy-making. How can this finding be explained?

One possibility - as vaguely set out by Sabatier and Weible (2007: 199) - is that the ACF was previously too pluralism-centric, and that corporatist systems work differently. Nonetheless, while the typical corporatist patterns of fuzzy coalitions with brokers in between (Sabatier and Weible 2007: 200) are observable in 1997 and, to a lesser extent, within coalitions in the other years, other studies in corporatist political systems have 
found a prevalence of competing coalitions (for an overview of studies and their geographic setting, see Sabatier 1998: 100), which indicates that more fine-grained institutional differences between subsystems than the simple corporatism-pluralism dimension are likely to account for this variation.

In this perspective, the variation could be related to differences between subsystems or policy sectors rather than polities at large (cf. Lowi 1972). Old-age security is a typical redistributive policy sector, in which the state collects taxes and redistributes them to other individuals. In other words, state authorities have a prevalent role in this kind of subsystem. In contrast, regulative policy sectors like telecommunication or environmental policy are characterized by the surveillance of market or private actors by the state. Regulatory interventions are only made if the provision of infrastructures or public goods is inefficient. Regulative policy subsystems may thus be more prone to competition by interest groups than redistributive subsystems. Hence, in redistributive subsystems like old-age security, policy change may be characterized by a transition between stable hegemonic coalitions, with polarization and learning across coalitions occurring in the transition phase, while regulative subsystems may be characterized by the competition of advocacy coalitions as confirmed by numerous studies. In fact, most ACF applications were conducted in policy sectors with a highly regulatory character (for an early overview, see Sabatier 1998: 100), which is why most studies could confirm the original predictions. The ACF allows for this possibility - albeit with a different predicted pattern -, but does not pursue it any further: "subsystem dynamics may vary by policy type [...]. For example, one might expect regulatory and redistributive subsystems to be characterized by multiple coalitions, while distributive policies may usually have a single (pork-barrel) coalition except during periods when cost-bearers (e.g. taxpayers or environmentalists) are activated" (Sabatier 1988: 159).

Future research may shed more light on these open questions, in particular on why some subsystems are characterized by competition and others by hegemony and whether redistribution versus regulation can explain this difference.

\subsection{Transitions and major policy change}

Furthermore, the case study presented above suggests that a transition between two normal states or subsystem equilibria may be required for major policy change to occur. In the case of a single hegemonic coalition, the transition phase features two interrelated processes: polarization and learning across coalitions (where learning is a result of the polarization that has already begun).

This leaves several interesting questions to be explored by future research: is the transition observed here a general pattern in subsystems with a hegemonic coalition, or is this an idiosyncratic case? Is there a similar transition phase in subsystems with two or more competing coalitions? And what does such a realignment in pluralist subsystems look like at the discursive level?

Moreover, the reasons why a transition is initiated in the first place must be disentangled. The ACF allows for external perturbations to initiate learning processes across coalitions, hence leading to major policy change. As it seems, in subsystems with a single hegemonic coalition, polarization is a necessary additional mechanism that must take place before learning occurs. What are the mechanisms that trigger polarization? In the pension subsystem analyzed above, the literature suggests several institutional forces 
ranging from the national election in 1998 over party politics to substitution of agency executives (see the case study background section).

\section{Conclusion}

This article presents two key findings. First, it shows how major policy change comes about. In the case study of German pension politics, preference polarization and shifting coalition memberships of early adopters have been pinpointed at the level of policy beliefs (the "discursive" level) as necessary conditions for third-order policy change to happen. The Riester reform in 2001 was predated by a shift from one hegemonic advocacy coalition to a bipolarization and finally to the replacement of the former by a new dominant advocacy coalition. In this process, some key actors ("early adopters") switched their affiliation over time, initiating a diffusion process and culminating in an erosion of the pension consensus.

Second, discourse network analysis is presented as a viable measurement instrument for the analysis of policy debates over time. The approach is able to graph relational changes at the level of policy core policy preferences and hence the belief component of advocacy coalitions and subsystems.

The results presented here also make a genuinely new contribution to the analysis of German pension politics in the public policy literature. For the first time, the oftenhypothesized ideational changes among actors were operationalized in a systematic way.

But more importantly, the results may have implications for other policy subsystems and other polities. Is policy change in subsystems always predated by a discursive polarization which looks like the one identified here? - Or may this pattern of polarization covary with redistributive versus regulative policy subsystems or other factors like technical complexity, moral tension, institutionalization of the policy sector, the existence of a discursive forum like a widely-read newspaper, or other variables related to the subsystem under scrutiny? Under what conditions is "normal" (that is, stable) policy-making accompanied by the presence of only one hegemonic coalition, as witnessed here, and under what circumstances is politics over a decade or more multipolar and conflictual, as suggested by the ACF (Sabatier 1998)? Do governmental actors usually act as bridges, or "brokers" (Sabatier 1998), between advocacy coalitions when a normal-state discourse is multipolar, or is this pattern more prevalent within dominant coalitions in corporatist settings, as the results in 1997 imply (see also Sabatier and Weible 2007: 200)? And finally, what rational, boundedly rational and cognitive mechanisms can explain why actors contribute certain solution concepts to the public debate at certain points in time? The toolbox of social network analysis and in particular the approach of discourse network analysis can help to answer questions like these. It facilitates the operationalization of the apparently ill-defined phenomenon of political discourse and opens up a new and previously inaccessible research agenda.

\section{A The discourse network model in matrix notation}

The descriptive discourse network model was presented in graph-theoretic notation. For the sake of clarity, the model is presented in matrix notation in this appendix.

The information encoded in a collection of articles can be represented by a fourdimensional array of actors, concepts, agreement relations and time points: $\underset{m \times n \times l \times k}{\mathbf{X}}$. 
This array can be broken down into a set of affiliation matrices for each time point and each relation separately: $\underset{\substack{m \times n \\ \mathbf{X}_{r, t}}}{ }$. In such an affiliation matrix, actors occupy the row labels and concepts the column labels. A cell entry of $x_{i j}=1$ denotes that actor $i$ refers to concept $j$ in a certain way (relation $r$ ) during time period $t$. A cell entry of $x_{i j}=0$ denotes that actor $i$ does not refer to concept $j$ in the specified way during $t$.

An actor congruence network can be computed by multiplying the affiliation matrix by its transpose:

$$
\mathbf{Y}_{r, t}^{\mathrm{a}}:=\mathbf{X}_{r, t} \mathbf{X}_{r, t}^{T}
$$

This yields an $m \times m$ square co-occurrence matrix with the edge weights as the cell entries - for each of the two agreement relations separately. Next, the matrices for the different agreement relations must be combined into a single matrix $\mathbf{Y}_{t}^{\mathrm{a}}$. This can be simply done by adding up the two matrices. Plugged together, the actor congruence matrix can be obtained by computing

$$
\mathbf{Y}_{t}^{\mathrm{a}}:=\sum_{r=1}^{l}\left(\mathbf{X}_{r, t} \mathbf{X}_{r, t}^{T}\right)
$$

In order to normalize the edge weights stored in $\mathbf{Y}_{t}^{\mathrm{a}}$, one first has to generate an aggregated affiliation matrix by adding up the two separate agreement relations. The resulting matrix does not distinguish between positive and negative referral anymore:

$$
\mathbf{X}_{t}=\sum_{r=1}^{l} \mathbf{X}_{r, t}
$$

This matrix must be dichotomized, i e., non-zero elements must be recoded as 1 :

$$
\forall x_{i j}: x_{i j}^{\text {dich }}=\left\{\begin{array}{l}
1 \text { if } x_{i j}>0 \\
0 \text { if } x_{i j}=0
\end{array}\right.
$$

In the dichotomized, aggregated affiliation matrix $\mathbf{X}_{t}^{\text {dich }}$, let $x_{i \bullet}^{\text {dich }}$ denote the row sum of actor $i$ (with $j \leq n$ being the index for the concepts):

$$
x_{i \bullet}^{\mathrm{dich}}=\sum_{j=1}^{n} x_{i j}^{\mathrm{dich}}
$$

A weighted edge $y_{i j}$ in the congruence network $\mathbf{Y}_{t}^{a}$, as defined in equation 9, can then be normalized by dividing it by the average row sum (in the affiliation matrix) for row actor $i$ and column actor $j$ in the congruence matrix, which is equivalent to equation 7 :

$$
\forall y_{i j}: \Phi\left(y_{i j}\right)=\frac{2 y_{i j}}{x_{i \bullet}^{\text {dich }}+x_{j \bullet}^{\text {dich }}}
$$

\section{References}

Barranco, J. and Wisler, D. (1999). Validity and Systematicity of Newspaper Data in Event Analysis. European Sociological Review, 15(3):301-322.

Baumgartner, F. R. and Jones, B. D. (1991). Agenda Dynamics and Policy Subsystems. The Journal of Politics, 53(4):1044-1074. 
Berkel, B., Börsch-Supan, A., Ludwig, A., and Winter, J. (2004). Sind die Probleme der Bevölkerungsalterung durch eine höhere Geburtenrate lösbar? Perspektiven der Wirtschaftspolitik, 5(1):71-90.

Birg, H. (2002). Demographic Ageing and Population Decline in Twenty-First-Century Germany: Consequences for the Systems of Social Insurance. Population Bulletin of the United Nations, 44-45:103-134.

Brandes, U. and Pich, C. (2009). An Experimental Study on Distance-based Graph Drawing. In Proceedings of the $16^{\text {th }}$ International Symposium on Graph Drawing (GD '08), LNCS 5417, pages 218-229, Berlin. Springer.

Brandes, U. and Wagner, D. (2004). visone - Analysis and Visualization of Social Networks. In Jünger, M. and Mutzel, P., editors, Graph Drawing Software, pages 321-340. Springer, Berlin/Heidelberg.

Breyer, F. (2000). Kapitaldeckungs- versus Umlageverfahren. Perspektiven der Wirtschaftspolitik, 1(4):383-405.

Börsch-Supan, A. and Wilke, C. B. (2003). The German Public Pension System: How it Was, How it Will Be. Discussion Paper 34-2003, Michigan Retirement Research Center (MRRC), Mannheim.

Finney, H. C. (1981). Improving the Reliability of Retrospective Survey Measures. Evaluation Review, 5(2):207-229.

Fisher, D. R., Leifeld, P., and Iwaki, Y. (2013). Mapping the Ideological Networks of American Climate Politics. Climatic Change. Forthcoming.

Fisher, D. R., Waggle, J., and Leifeld, P. (2012). Where does Political Polarization Come From? Locating Polarization Within the U.S. Climate Change Debate. American Behavioral Scientist. Forthcoming.

Geweke, J. and Martin, D. L. (2002). Pitfalls in Drawing Policy Conclusions from Retrospective Survey Data: The Case of Advertising and Underage Smoking. Journal of Risk and Uncertainty, 25:111-131.

Goldstein, J. R., Sobotka, T., and Jasilioniene, A. (2009). The end of 'lowest-low' fertility? Population and Development Review, 35(4):663-699.

Graf von der Schulenburg, J.-M. and Wähling, S. (1997). Das Elend der Alterssicherung in Deutschland. In Becker, G. S., Dahlmanns, G., Homburg, S., Neumann, M., Graf von der Schulenburg, J.-M., and Wähling, S., editors, Rentenkrise. Und wie wir sie meistern können, number 21 in Kleine Handbibliothek, pages 27-59. Frankfurter Institut - Stiftung Marktwirtschaft und Politik, Bad Homburg.

Hall, P. A. (1993). Policy Paradigms, Social Learning, and the State: the Case of Economic Policymaking in Britain. Comparative Politics, 25(3):275-296.

Heclo, H. (1978). Issue Networks and the Executive Establishment. In King, A., editor, The New American Political System, pages 87-124. American Enterprise Institute. 
Henry, A. D., Lubell, M., and McCoy, M. (2011). Belief Systems and Social Capital as Drivers of Policy Network Structure: The Case of California Regional Planning. Journal of Public Administration Research and Theory, 21(3):419-444.

Hinrichs, K. (2004). Alterssicherungspolitik in Deutschland: Zwischen Kontinuität und Paradigmenwechsel. In Stykow, P. and Beyer, J., editors, Gesellschaft mit beschränkter Hoffnung. Reformfähigkeit und die Möglichkeit rationaler Politik, pages 266-286. VS Verlag für Sozialwissenschaften, Wiesbaden.

Ingold, K. M. (2011). Network Structures within Policy Processes: Coalitions, Power, and Brokerage in Swiss Climate Policy. Policy Studies Journal, 39(3):435-459.

Janson, C.-G. (1990). Retrospective Data, Undesirable Behavior, and the Longitudinal Perspective. In Magnusson, D. and Bergman, L. R., editors, Data Quality in Longitudinal Research, chapter 6, pages 100-121. Cambridge University Press, Cambridge.

Jenkins-Smith, H. C., St. Clair, G. K., and Woods, B. (1991). Explaining Change in Policy Subsystems: Analysis of Coalition Stability and Defection over Time. American Journal of Political Science, 35(4):851-880.

Jones, B. D. and Baumgartner, F. R. (2005). A Model of Choice for Public Policy. Journal of Public Administration Research and Theory, 15(3):325-351.

Koopmans, R. (1996). New Social Movements and Changes in Political Participation in Western Europe. West European Politics, 19(1):28-50.

Kriesi, H. (1995). New Social Movements in Western Europe: A Comparative Analysis. University of Minnesota Press, Minnesota.

Lamping, W. and Rüb, F. W. (2004). From the Conservative Welfare State to an 'Uncertain Something Else': German Pension Politics in Comparative Perspective. Policy \& Politics, 32(2):169-191.

Leifeld, P. (2011). Discourse Networks and German Pension Politics. PhD thesis, University of Konstanz, Department of Politics and Public Administration, Konstanz.

Leifeld, P. (2013). Discourse Network Analyzer Manual. Swiss Federal Institute of Aquatic Science and Technology (Eawag), Dübendorf, Switzerland. Available at http://www . philipleifeld.de.

Leifeld, P. and Haunss, S. (2012). Political Discourse Networks and the Conflict over Software Patents in Europe. European Journal of Political Research, 51(3):382-409.

Leifeld, P. and Schneider, V. (2012). Information Exchange in Policy Networks. American Journal of Political Science, 53(3):731-744.

Lesthaeghe, R. and Willems, P. (1999). Is Low Fertility a Temporary Phenomenon in the European Union? Population and Development Review, 25(2):211-228.

Lowi, T. J. (1972). Four Systems of Policy, Politics, and Choice. Public Administration Review, 32(4):298-310. 
Lubell, M. N., Scholz, J. T., Berardo, R., and Robins, G. (2012). Testing Policy Theory with Statistical Models of Networks. Policy Studies Journal, 40(3):351-374.

Mintrom, M. and Vergari, S. (1996). Advocacy Coalitions, Policy Entrepreneurs, and Policy Change. Policy Studies Journal, 24(3):420-434.

Nadeau, R., Cloutier, E., and Guay, J.-H. (1993). New Evidence about the Existence of a Bandwagon Effect in the Opinion Formation Process. International Political Science Review, 14(2):203-213.

Ney, S. (2000). Are You Sitting Comfortably... Then We'll Begin: Three Gripping Policy Stories About Pension Reform. Innovation: The European Journal of Social Science Research, 13(4):341-371.

Ney, S. (2001). Pension Reform in Germany. Technical report, The Interdisciplinary Centre for Comparative Research in the Social Sciences (ICCR), Vienna. Public Participation and the Pension Policy Process: The Citizen and Pension Reform (PENREF Project). Deliverable D2. Available at http://www.iccr-international.org/ pen-ref/docs/penref-d2-de.pdf.

Nohrstedt, D. (2010). Do Advocacy Coalitions Matter? Crisis and Change in Swedish Nuclear Energy Policy. Journal of Public Administration Research and Theory, 20(2):309333.

Oeppen, J. and Vaupel, J. W. (2002). Broken Limits to Life Expectancy. Science, 296(5570):1029-1031.

Pappi, F. U. and Henning, C. H. C. A. (1998). Policy Networks: More than a Metaphor? Journal of Theoretical Politics, 10(4):553-575.

Sabatier, P. A. (1987). Knowledge, Policy-Oriented Learning, and Policy Change: An Advocacy Coalition Framework. Science Communication, 8(4):649-692.

Sabatier, P. A. (1988). An Advocacy Coalition Framework of Policy Change and the Role of Policy-Oriented Learning Therein. Policy Sciences, 21(2):129-168.

Sabatier, P. A. (1998). The Advocacy Coalition Framework: Revisions and Relevance for Europe. Journal of European Public Policy, 5(1):98-130.

Sabatier, P. A. and Weible, C. M. (2007). The Advocacy Coalition Framework. In Sabatier, P. A., editor, Theories of the Policy Process, pages 189-220. Westview Press, Boulder, CO.

Scherbov, S. and Sanderson, W. C. (2010). Negative Folgen der Alterung bislang überbewertet. Neue Maßzahlen für aktuelle Bevölkerungsentwicklung. Demografische Forschung Aus Erster Hand, 7(4):1-2.

Schmidt, V. A. (2002). Does Discourse Matter in the Politics of Welfare State Adjustment? Comparative Political Studies, 35(2):168-193.

Schmidt, V. A. (2010). Taking Ideas and Discourse Seriously: Explaining Change through Discursive Institutionalism as the Fourth 'New Institutionalism'. European Political Science Review, 2(01):1-25. 
Schmähl, W. (2000). Perspektiven der Alterssicherungspolitik in Deutschland - Über Konzeptionen, Vorschläge und einen angestrebten Paradigmenwechsel. Perspektiven der Wirtschaftspolitik, 1(4):407-430.

Schneider, V. (1992). The Structure of Policy Networks. European Journal of Political Research, 21(1-2):109-129.

Schulze, I. and Jochem, S. (2007). Germany: Beyond Policy Gridlock. In Immergut, E., Anderson, K. M., and Schulze, I., editors, Handbook of West European Pension Politics, chapter 14, pages 660-710. Oxford University Press, Oxford.

Sobotka, T. (2004). Is Lowest-Low Fertility in Europe Explained by the Postponement of Childbearing? Population and Development Review, 30(2):195-220.

Sobotka, T., Skirbekk, V., and Philipov, D. (2011). Economic Recession and Fertility in the Developed World. Population and Development Review, 37(2):267-306.

Trampusch, C. (2008). Sequenzorientierte Policy-Analyse. Warum die Rentenreform von Walter Riester nicht an Reformblockaden scheiterte. In Janning, F. and Toens, K., editors, Die Zukunft der Policy-Forschung. Theorien, Methoden, Anwendungen, pages 259-278. VS Verlag für Sozialwissenschaften, Wiesbaden.

Tsebelis, G. (1995). Decision Making in Political Systems: Veto Players in Presidentialism, Parliamentarism, Multicameralism and Multipartyism. British Journal of Political Science, 25:289-325.

van der Vaart, W., van der Zouwen, J., and Dijkstra, W. (1995). Retrospective Questions: Data Quality, Task Difficulty, and the Use of a Checklist. Quality \& Quantity, 29:299315 .

Wehlau, D. (2009). Lobbyismus und Rentenreform. Der Einfluss der Finanzdienstleistungsbranche auf die Teil-Privatisierung der Alterssicherung. VS Verlag, Wiesbaden.

Weible, C. M. (2005). Beliefs and Perceived Influence in a Natural Resource Conflict: An Advocacy Coalition Approach to Policy Networks. Political Research Quarterly, 58(3):461-475.

Weible, C. M. (2010). Collaborative Institutions, Functional Areas, and Beliefs: What Are Their Roles in Policy Networks? In Self-Organizing Federalism: Collaborative Mechanisms to Mitigate Institutional Collective Action, pages 179-203. Cambridge University Press.

Zafonte, M. and Sabatier, P. (2004). Short-Term Versus Long-Term Coalitions in the Policy Process: Automotive Pollution Control, 1963-1989. The Policy Studies Journal, 32(1):75-107. 


\title{
- Online Appendix - \\ Reconceptualizing Major Policy Change in the Advocacy Coalition Framework
}

\author{
A Discourse Network Analysis of German Pension Politics
}

Philip Leifeld 


\section{List of concepts in the dataset}

\section{Retrenchment within the PAYG paradigm}

- Cut pensions

- Deferred taxation

- Demographic factor

- Extend capital-covered provisional fund

- Include other assets in contributions

- Increase contribution assessment ceiling

- Increase contributions

- Increase employees' share of contributions

- Introduce a ceiling for pension entitlements

- Let employees participate in company's annual profits

- Machine tax

- Subtract assets from pension level

- Tax life insurances

- Tax pensions

- Tie pension formula to economic development

- Use surplus of health care insurance

\section{Strengthening the insurance principle}

- Cut back invalidity or widows' pensions

- Cut back the administrative apparatus

- Extend pension entitlements for parenting periods

- Grant pension entitlements for educational periods

- Grant pension entitlements for military or alternative service

- Grant pension entitlements to ethnic German emigrants

- Grant pension entitlements to forced laborers 
- Insure periods without contributions

- Minimum pension

- Regionalize the pension system

- Remove non-insurance benefits

- Use pension system to finance German reunification

\section{Increasing the number of contributors}

- Affirmative action for families

- Child care

- Education

- Family fund

- Fight early retirement

- Fight unemployment

- Grant pension entitlements to volunteers

- Immigration

- Include clerks in the pension system

- Include low-income earners in the pension system

- Include pseudo self-employed people in the pension system

- Include self-employed people in the pension system

- Increase female labor participation

- Increase fertility

- Increase retirement age

- Increase working life

- Increase working life by decreasing number of school years

- Link contribution or pension level to number of children

- Reduce supplementary pensions

- Separate pension funds for independent professions

- Universal contribution 


\section{System change}

- Capital market risk

- Compensate for double burden by increasing public debt

- Compulsory contributions

- Contribution-based PAYG system

- Convert working time accounts into old-age provision

- Double burden during transition

- Effort-based pensions

- Flat rate pensions

- Full transition to a private capital cover system

- Manipulation by politicians

- Occupational pensions

- Occupational pensions - Direct insurance

- Occupational pensions - Direct commitment

- Occupational pensions - Employee funds

- Occupational pensions - Relief funds

- Occupational pensions - Pension funds

- Occupational pensions - Mediate system

- Partial transition to a private capital cover system

- Promote home ownership

- Returns are higher in a capital cover system

- Subsidies from the national budget 


\section{List of actors in the dataset}

ABA Arbeitsgemeinschaft für betriebliche Altersversorgung [financial]

ABV Arbeitsgemeinschaft berufsständischer Versorgungseinrichtungen e. V.

ACC American Chamber of Commerce in Germany e. V.

AG-GesM Gesamtmetall. Die Arbeitgeberverbände der Metall- und Elektro-Industrie

AG-K Arbeitgeberverband Kautschuk

AGAWP Arbeitsgruppe Alternative Wirtschaftspolitik - Memorandum-Gruppe - Memogruppe [science]

AGP Arbeitsgemeinschaft Partnerschaft in der Wirtschaft e. V.

AGV Arbeitgeberverband der Versicherungsunternehmen in Deutschland [financial]

AK-BPF Arbeitskreis Betriebliche Pensionsfonds (Gerke-Kommission) [science]

AOK AOK-Bundesverband [financial]

ARGE Arbeitsgemeinschaft Deutscher Wirtschaftswissenschaftlicher Forschungsinstitute e. V. [science]

ASF Arbeitsgemeinschaft Sozialdemokratischer Frauen [social]

ASU Arbeitsgemeinschaft Selbständiger Unternehmer e. V.

Allianz Allianz [financial]

Awo Arbeiterwohlfahrt [social]

BA Bundesanstalt für Arbeit [governmental]

BAG Bundesarbeitsgemeinschaft der Mittel- und Großbetriebe des Einzelhandels e. V.

BAVC Bundesarbeitgeberverband Chemie

BBS Bundesverband Baustoffe, Steine und Erden

BDA Bundesvereinigung der Deutschen Arbeitgeberverbände e. V.

BDF Bundesverband Deutscher Fertigbau [financial]

BDH Bundesvereinigung Deutscher Handelsverbände

BDI Bundesverband der Deutschen Industrie e. V.

BDS Der Bund der Selbständigen/Deutscher Gewerbeverband

BDZV Bundesverband Deutscher Zeitungsverleger e. V.

BFS Bundesverband der Filialbetriebe und Selbstbedienungs-Warenhäuser

BFW Bundesverband Freier Immobilien- und Wohnungsunternehmen e. V. [financial]

BGA Bundesverband Großhandel, Außenhandel, Dienstleistungen e. V.

BJU Bundesverband Junger Unternehmer (Die Jungen Unternehmer)

BK Bundeskanzler und Bundeskanzleramt [governmental]

BKU Bund Katholischer Unternehmer e. V.

BMAS Bundesministerium für Arbeit und Soziales [governmental]

BMF Bundesministerium der Finanzen [governmental] 
BMF-WBR Wissenschaftlicher Beirat beim Bundesfinanzministerium [science]

BMFSFJ Bundesministerium für Familie, Senioren, Frauen und Jugend [governmental]

BMG Bundesministerium für Gesundheit [governmental]

BMVBW Bundesministerium für Verkehr, Bau- und Wohnungswesen [governmental]

BMWi Bundesministerium für Wirtschaft und Technologie [governmental]

BMWi-WBR Wissenschaftlicher Beirat beim Bundesministerium für Wirtschaft und Technologie [science]

BRH Bund der Ruhestandsbeamten, Rentner und Hinterbliebenen [social]

BSZK Bayerisch-Sächsische Zukunftskommission [science]

BSozG Bundessozialgericht [governmental]

BVI Bundesverband Deutscher Investment-Gesellschaften e.V. (Bundesverband Investment und Asset Management e. V.) [financial]

BVK Bundesverband Deutscher Versicherungs-Kaufleute [financial]

BVKS Bundesvereinigung der kommunalen Spitzenverbände [other]

BVdB Ausschuß für Wirtschafts- und Währungspolitik im Bundesverband deutscher Banken [financial]

BVerfG Bundesverfassungsgericht [governmental]

Bau-AG Bau-Arbeitgeber

Bausparkasse Schwäbisch Hall AG Bausparkasse Schwäbisch Hall AG [financial]

Bayer AG Bayer AG

BdB Bundesverband deutscher Banken [financial]

BdSt Bund der Steuerzahler e. V. [other]

BdV Bund der Versicherten [social]

Bertelsmann Stiftung Bertelsmann Stiftung

BfA Bundesversicherungsanstalt für Angestellte [governmental]

BfA-AG Bundesversicherungsanstalt für Angestellte; Arbeitgeberflügel

BfA-AN Bundesversicherungsanstalt für Angestellte; Arbeitnehmerflügel [social]

BfB Bundesverband der Freien Berufe

Buba Deutsche Bundesbank [governmental]

Bundesknappschaft Bundesknappschaft [governmental]

Bundesrechnungshof Bundesrechnungshof [governmental]

Burda Burda Druck GmbH

CAWM Centrum für angewandte Wirtschaftsforschung [science]

CDA Christlich-Demokratische Arbeitnehmerschaft [social]

CDH Centralvereinigung Deutscher Wirtschaftsverbände für Handelsvermittlung und Vertrieb

CDU Christlich Demokratische Union Deutschlands [governmental] 
CDU-FU Frauenunion [social]

CDU-JG CDU - Junge Gruppe [young]

CDU-JU Junge Union [young]

CDU-MIT Mittelstands- und Wirtschaftsvereinigung der CDU/CSU

CDU-SU Senioren-Union [social]

CDU-WR CDU-Wirtschaftsrat

CKAG Colonia Konzern Aktiengesellschaft [financial]

CSU Christlich-Soziale Union in Bayern e.V. [governmental]

Cardiff University Cardiff University [science]

Colonia Nordstern LV Colonia Nordstern Lebensversicherungen [financial]

Columbia University Columbia University in the City of New York [science]

Continentale VG Continentale Versicherungs-Gruppe [financial]

DAG Deutsche Angestellten Gewerkschaft [social]

DAI Deutsches Aktieninstitut [financial]

DAK Deutsche Angestellten-Krankenkasse [financial]

DB Deutsche Bank AG [financial]

DB Research Deutsche Bank Research [financial]

DBBu Deutscher Beamtenbund [other]

DBV Winterthur DBV Winterthur [financial]

DCV Deutscher Caritasverband e.V. [social]

DEHOGA Deutsche Hotel- und Gaststättenverband e. V.

DFV Deutscher Familienverband e. V. [social]

DGB Deutscher Gewerkschaftsbund [social]

DGVN Deutsche Gesellschaft für die Vereinten Nationen [other]

DGZ-Deka-Bank, Frankfurt DekaBank Deutsche Girozentrale [financial]

DIA Deutsche Institut für Altersvorsorge [financial]

DIHT Deutscher Industrie- und Handelskammertag

DIS Deutsche Industrie Service AG

DIT Deutscher Investment Trust Gesellschaft für Wertpapieranlagen mbH [financial]

DIW Berlin Deutsches Institut für Wirtschaftsforschung [science]

DSGV Deutscher Sparkassen- und Giroverband [financial]

DST Deutscher Städtetag [other]

DStGB Deutscher Städte- und Gemeindebund [other]

DVAG Deutsche Vermögensberatung AG [financial] 
DVfVW Deutscher Verein für Versicherungswissenschaft e. V. [financial]

DWS Investment GmbH DWS Investment GmbH [financial]

DeuBiKo Deutsche Bischofskonferenz [social]

Deutscher Frauenrat Deutscher Frauenrat e. V. [social]

Deutscher Juristentag Deutscher Juristentag [other]

Dresdner Bank Dresdner Bank AG [financial]

EKD Evangelische Kirche in Deutschland [social]

EZB Europäische Zentralbank [other]

Enquete-Kommission Enquete-Kommission Demographischer Wandel, 1992-2002 [governmental]

Ergo Versicherungsgruppe AG ERGO Versicherungsgruppe AG [financial]

Europa-Versicherungen Europa-Versicherungen [financial]

Europäische Kommission Europäische Kommission [other]

Evangelisches Siedlungswerk Evangelisches Siedlungswerk in Deutschland e. V. [financial]

FAZ Frankfurter Allgemeine Zeitung [other]

FDK Familienbund der Katholiken [social]

FDP Freie Demokratische Partei [governmental]

FES-Managerkreis Friedrich-Ebert-Stiftung, Managerkreis

Fidelity Investments Fidelity Investments [financial]

Fitch IBCA Fitch Ratings [financial]

GDV Gesamtverband der Deutschen Versicherungswirtschaft [financial]

GVE Gemeinschaftsverband des Deutschen Einzelhandels

GdW Bundesverband deutscher Wohnungs- und Immobilienunternehmen [financial]

Gesamttextil Gesamttextil e.V. - Dachverband der deutschen Textilindustrie

Gevaert Gevaert Photo-Producten, N. V.

Goldman, Sachs und Co. Goldman, Sachs und Co. [financial]

Grüne Bündnis 90/Die Grünen [governmental]

HBV Gewerkschaft Handel, Banken und Versicherungen [social]

HDB Hauptverband der Deutschen Bauindustrie e.V. [financial]

HDE Handelsverband Deutschland e. V. - Der Einzelhandel

HDH Hauptverband der Deutschen Holz und Kunststoffe verarbeitenden Industrie und verwandter Industriezweige

HU Berlin Humboldt-Universität Berlin [science]

HWWA Hamburgisches Welt-Wirtschafts-Archiv; HWWA-Institut für Wirtschaftsforschung [science]

Haus und Grund Zentralverband der Deutschen Haus-, Wohnungs- und Grundeigentümer e. V. [financial]

Heubeck-Feri Pension Asset Consulting Heubeck-Feri Pension Asset Consulting [financial] 
IG BAU Industriegewerkschaft Bauen-Agrar-Umwelt [social]

IG BCE Industriegewerkschaft Bergbau, Chemie, Energie [social]

IG Medien Industriegewerkschaft Medien - Druck und Papier, Publizistik und Kunst [social]

IGM Industriegewerkschaft Metall [social]

IHK Köln Industrie- und Handelskammer Köln

IW Institut der deutschen Wirtschaft Köln e. V.

IWF Internationaler Währungsfonds [other]

IWG Institut für Wirtschaft und Gesellschaft Bonn e. V.

IWH Institut für Wirtschaftsforschung Halle [science]

IZA Institut zur Zukunft der Arbeit [science]

Iduna/Nova Iduna/Nova [financial]

IfW Institut für Weltwirtschaft an der Universität Kiel [science]

Ifo ifo Institut für Wirtschaftsforschung e. V. [science]

Initiative für Deutschland Initiative für Deutschland

Initiative pro Handelsvertreter Initiative pro Handelsvertreter

Institut Finanzen und Steuern Institut Finanzen und Steuern, Bonn [science]

J. P. Morgan J. P. Morgan [financial]

J.M. Voith AG J.M. Voith AG

JDW Junge Deutsche Wirtschaft [young]

JuLi Junge Liberale [young]

KDFB Katholischer Deutscher Frauenbund [social]

KFD Katholische Frauengemeinschaft Deutschlands [social]

KOS Koordinierungsstelle gewerkschaftlicher Arbeitslosengruppen [social]

KSD Katholischer Siedlungsdienst e.V. - Bundesverband für Wohnungswesen und Städtebau [financial]

Kirchen [social]

Kronberger Kreis Kronberger Kreis; Frankfurter Institut; Stiftung Marktwirtschaft

LBS BW Landesbausparkasse Baden-Württemberg [financial]

LBS Hessen-Thüringen Landesbausparkasse Hessen-Thüringen [financial]

LMU München Ludwig-Maximilians-Universität München [science]

LZB H, MV, SH Landeszentralbank Hamburg, Meckl.-Vorp. und Schleswig-Holst. [financial]

LZB Thüringen und Sachsen Landeszentralbank Thüringen und Sachsen [financial]

Ludwig-Erhard-Stiftung Ludwig-Erhard-Stiftung e. V.

MIT Massachusetts Institute of Technology [science]

MLP AG Marschollek, Lautenschläger und Partner AG [financial] 
MPI-SR Max-Planck-Institut für Sozialrecht [science]

MPIfG, Köln Max-Planck-Institut für Gesellschaftsforschung [science]

Metzler B. Metzler seel. Sohn \& Co. Kommanditgesellschaft auf Aktien [financial]

Morgan Stanley Morgan Stanley Dean Witter [financial]

NGG Gewerkschaft Nahrung-Genuss-Gaststätten [social]

OECD Organisation für wirtschaftliche Zusammenarbeit und Entwicklung [other]

PDS Partei des Demokratischen Sozialismus [governmental]

PR-Gruppe, Waiblingen PR-Gruppe, Waiblingen

PVZ Provinzial [financial]

Pensions Institute Pensions Institute [science]

Piepenbrock Piepenbrock-Unternehmensgruppe, Osnabrück

RB Roland Berger \& Partner

RWI Rheinisch-Westfälisches Institut für Wirtschaftsforschung [science]

SB Sozialbeirat [governmental]

SGZ-Bank Südwestdeutschen Genossenschafts-Zentralbank AG, Frankfurt [financial]

SPD Sozialdemokratische Partei Deutschlands [governmental]

SPD-60p Arbeitsgemeinschaft SPD 60 plus [social]

SPD-AGS Arbeitsgemeinschaft Selbständige in der SPD

SPD-AfA Arbeitsgemeinschaft für Arbeitnehmerfragen in der SPD [social]

SPD-Jusos Arbeitsgemeinschaft der Jungsozialistinnen und Jungsozialisten in der SPD [young]

SVR Sachverständigenrat zur Begutachtung der gesamtwirtschaftlichen Entwicklung [science]

Siemens AG Siemens AG

SoVD Sozialverband Deutschland e.V. [social]

TU Berlin Technische Universität Berlin [science]

Thilenius Management AG Thilenius Management AG

Thyssen Thyssen Stahl AG

Tierschutzpartei Partei Mensch Umwelt Tierschutz [governmental]

UG UnternehmensGrün e. V.

ULA Union Leitender Angestellter

Uni Bamberg Otto-Friedrich-Universität Bamberg [science]

Uni Bielefeld Universität Bielefeld [science]

Uni Bonn Rheinische Friedrich-Wilhelms-Universität Bonn [science]

Uni Bremen Universität Bremen [science]

Uni Erlangen-Nürnberg Friedrich-Alexander-Universität Erlangen-Nürnberg [science] 
Uni Frankfurt Johann Wolfgang Goethe-Universität Frankfurt am Main [science]

Uni Freiburg Albert-Ludwigs-Universität Freiburg [science]

Uni Heidelberg Ruprecht-Karls-Universität Heidelberg [science]

Uni Hohenheim Universität Hohenheim [science]

Uni Kiel Christian-Albrechts-Universität zu Kiel [science]

Uni Konstanz Universität Konstanz [science]

Uni Köln Universität zu Köln [science]

Uni Magdeburg Otto-von-Guericke-Universität Magdeburg [science]

Uni Mainz Johannes Gutenberg-Universität Mainz [science]

Uni Mannheim Universität Mannheim [science]

Uni Würzburg Julius-Maximilians-Universität Würzburg [science]

Union-Investment-Gesellschaft mbH Union-Investment-Gesellschaft mbH [financial]

Universität Frankfurt (Oder) Europa-Universität Viadrina [science]

Universität Halle-Wittenberg Martin-Luther-Universität Halle-Wittenberg [science]

Universität Hannover Gottfried Wilhelm Leibniz Universität Hannover [science]

Universität Tübingen Eberhard Karls Universität Tübingen [science]

Universtity of Chicago Universtity of Chicago [science]

VDH Verband deutscher Hypothekenbanken [financial]

VDM Verband der Deutschen Möbelindustrie [1iberal]

VDMA Verband Deutscher Maschinen- und Anlagenbau

VDR Verband Deutscher Rentenversicherungsträger [governmental]

VLVU Verband der Lebensversicherungsunternehmen e. V. [financial]

VMU Vereinigung Mittelständischer Unternehmer

VPRT Verband Privater Rundfunk und Telemedien

VW Volkswagen AG

VdK Sozialverband VdK Deutschland e. V. [social]

Veba AG Veba AG

Verband öffentlicher Versicherer Verband öffentlicher Versicherer [financial]

Verdi Vereinte Dienstleistungsgewerkschaft [social]

Verein für Socialpolitik Verein für Socialpolitik

Victoria Lebensversicherung Victoria Versicherungs-Gesellschaften [financial]

Volksfürsorge Holding AG Volksfürsorge Holding AG [financial]

WB Weltbank [other]

WIG Industrieinstandhaltung WIG Industrieinstandhaltung GmbH, Köln 
WJD Wirtschaftsjunioren Deutschlands [young]

Wimatik GmbH WiMatik Wirtschaftsmathematik GmbH [liberal]

ZDB Zentralverband des Deutschen Baugewerbes [financial]

ZDH Zentralverband des Deutschen Handwerks e. V. [liberal]

ZEW Zentrum für Europäische Wirtschaftsforschung [science]

ZdK Zentralkomitee der deutschen Katholiken [social]

Zukunftskommission Gesellschaft 2000 Zukunftskommission Gesellschaft 2000 [science]

vhw Deutsches Volksheimstättenwerk [liberal]

ÖTV Gewerkschaft öffentliche Dienste, Transport und Verkehr [social] 